\title{
The comparative African regional economics of globalization in financial allocation efficiency: the pre-crisis era revisited
}

\author{
Simplice A. Asongu ${ }^{1 *}$ (D) Joseph Nnanna ${ }^{2}$ and Vanessa S. Tchamyou ${ }^{1}$
}

\footnotetext{
* Correspondence: asongusimplice@ yahoo.com; asongus@afridev.org

${ }^{1}$ African Governance and Development Institute, P. O. Box 8413, Yaoundé, Cameroon Full list of author information is available at the end of the article
}

\begin{abstract}
This study assesses the role of globalization-fueled regionalization policies on the financial allocation efficiency of four economic and monetary regions in Africa from 1980 to 2008. Banking and financial system efficiency proxies are used as dependent variables and seven bundled and unbundled globalization variables are employed as independent indicators. The bundling is achieved by principal component analysis, while the empirical evidence is based on interactive fixed effects regressions. The findings are as follows. First, financial allocation efficiency is more sensitive to financial openness compared to trade openness and most sensitive to globalization. The relationship between allocation efficiency and globalization-fueled regionalization policies is defined by: (i) a Kuznets or inverted U-shaped curve in the UEMOA and CEMAC zones (evidence of decreasing returns for allocation efficiency from globalization-fueled regionalization) and (ii) a U-shaped relationship overwhelmingly in the COMESA and scantily in the EAC (increasing returns to allocation efficiency due to globalization-fueled regionalization). These relationships are relevant to the specific globalization dynamics within regions. Economic and monetary regions are more prone to surplus liquidity than pure economic regions are. Policy implications and measures for reducing surplus liquidity are also discussed.
\end{abstract}

Keywords: Globalization, Financial development, Regional integration, Panel, Africa

JEL classification: A10, D60, E40, O10, P50

\section{Introduction}

There are at least three motives for inquiring on the comparative African regional economics of globalization under financial allocation efficiency, notably, the growing relevance of regional integration, substantially documented concerns of surplus liquidity, and ongoing debates surrounding the effects of globalization. ${ }^{1}$

First, consistent with Asongu (2013a), integrated economies have several advantages, namely more efficiency in capital allocation (Chen et al. 2002); stimulation of cross-

\footnotetext{
${ }^{1}$ Openness and globalization are used interchangeably throughout the study.
}

\section{Springer Open}

(c) The Author(s). 2020 Open Access This article is distributed under the terms of the Creative Commons Attribution 4.0 International License (http://creativecommons.org/licenses/by/4.0/), which permits unrestricted use, distribution, and reproduction in any medium, provided you give appropriate credit to the original author(s) and the source, provide a link to the Creative Commons license, and indicate if changes were made. 
border flow of funds, improved volumes of trade transactions, more market liquidity, lower cost for investors (Kim et al. 2005); financial stability owing to the minimization of the probability of asymmetric shocks (Umutlu et al. 2010); and the amelioration of the capacity of economies to absorb shocks (Yu et al. 2010). These advantages, inter alia, have motivated a growing literature stream on economic integration in Africa (Njifen 2014; Kayizzi-Mugerwa et al. 2014; Akpan 2014). ${ }^{2}$ Second, financial intermediary development in Africa is limited by the substantially documented concerns of surplus liquidity that are constraining the optimal transformation of mobilized deposits into credit for economic operators (Saxegaard 2006; Asongu 2014a).

The recent global financial and European Monetary Union (EMU) crises have reignited the debate about the potential advantages of liberalization and regionalization, especially within the framework of financial allocation efficiency in developing countries (Asongu 2013b). Some authors consider that the recent global financial crisis has substantially unraveled the drawbacks of regionalization and liberalization because many developing economies that had previously experienced surges in inflows of foreign capital also experienced a sharp reversal in the same flows (Rodrik and Subramanian 2009; Kose et al. 2011; Asongu 2014b). Essentially, the financial channels that have fueled the global economic turmoil have resurfaced issues surrounding the appeals of globalization and its corresponding externalities (e.g., volatility and growth) in developing countries. ${ }^{3}$

The skeptical literature strand starkly contrasts with the theoretical appeals of globalization and regionalization, which are expected to be high in developing nations. From a theoretical perspective, globalization/regionalization should promote international/regional risk-sharing and efficient capital allocation. These potential rewards are expected to be higher in developing nations compared to their developed counterparts because poorer countries are labor-rich but have scarce capital. Hence, given their higher marginal productivity of capital, globalization/ regionalization enables the flow of capital from capital-rich to capital-poor countries. Moreover, developing countries are also expected to enjoy higher welfare gains because they are characterized by more volatile outputs compared to their developed counterparts (Kose et al. 2011; Asongu 2014b).

The current wave of regionalization/globalization efforts began in the 1980s with an increase in the cross-border trade and financial flows between advanced and developing nations. The integration processes were facilitated by the liberalization of capital controls in many nations because it was estimated that growing cross-border flows would engender substantial rewards in terms of capital allocation and enhance international risk-sharing possibilities. According to Kose et al. (2006), many developing countries rapidly embraced integration polices because the anticipated rewards were higher compared to those for developed nations. Unfortunately, the surge in financial flows was

${ }^{2}$ Other recent studies within this literature stream include Baricako and Ndongo (2014), Ebaidalla and Yahia (2014), Charaf-Eddine and Strauss (2014), Nshimbi and Fioramonti (2014), Ofa and Karingi (2014), Shuaibu (2015), and Tumwebaze and Ijjo (2015).

${ }^{3}$ The benefits of globalization for developing countries are still subject to a heated debate. Although there is more consensus on the positive welfare effects of openness (Spatarenu and Manole 2010; Welch and Wacziarg 2008), some authors still caution on the need to progressively lift trade barriers only in tandem with economic development (Henry 2007). Capital and trade account openness (globalization) are perceived by many researchers not only as sources of growth, but also as means for financial development (Baltagi et al. 2009; Hanh 2010). 
associated with financial and currency crises in the late 1980s and 1990s. The pattern of these crises motivated scholars to advocate that, compared to developed countries, developing nations that liberalized their capital and trade accounts have been affected more by global crises (Henry 2007; Kose et al. 2011; Asongu 2013b).

However, the recent literature on the effect of globalization on financial development has failed to consider the comparative economics of regional integration in African countries. Henry's (2007) and Kose et al.'s (2011) hypothesis of initial financial development conditions for financial development benefit from financial globalization have been investigated by Asongu (2014b) who further established thresholds for the rewards of financial globalization. In the post-crisis literature, Price and Elu (2014) have concluded that credit contraction during the 2008-2009 financial crisis has been associated with more adverse growth externalities in sub-Saharan African (SSA) nations that belong to the French African Colonies' (CFA) currency union. Asongu (2013c) has investigated real and monetary policy convergence in the CFA zone in light of the EMU crisis, concluding there is an absence of policy harmonization in the common responses to serious disequilibria. Motelle and Biekpe (2015) have examined whether enhanced financial integration is a source of domestic financial sector instability to confirm Kose et al.'s (2011) hypothesis within the framework of the Southern African Development Community (SADC). Asongu et al. (2015a) have extended Price and Elu's (2014) and Motelle and Biekpe's (2015) studies in the context of the pre- and postcrisis effects of financial globalization in domestic financial development to confirm the relevance of the debate on the rewards of liberalization.

In the 1980s and 1990s, most African countries embarked in structural and policy adjustments that had the ultimate goal of stimulating financial development and economic growth (Janine and Elbadawi 1992; Asongu 2013b). As the first generation of reforms, policies consisted of abolishing explicit controls on the allocation and price of credit, allowance of interest rates to be determined by the market, reduction of direct government intervention in bank credit decisions, and relaxation of controls on international capital flows (see Asongu 2013b). The second generation of reforms targeted institutional and structural constraints, namely (i) enhancement of regulatory, legal, institutional, and supervisory environments; (ii) restoration of bank soundness; and (iii) rehabilitation of financial infrastructure (Batuo et al. 2010; Batuo and Asongu 2015).

Unfortunately, despite the two decades of globalization-fueled regionalization policies and reforms in the financial sector, African economies have not achieved remarkable progress in tackling the substantial surplus liquidity (Saxegaard 2006; Fouda 2009; Asongu 2014a). Hence, this inquiry on financial allocation efficiency is justified by an apparent policy syndrome on one hand and a missing link in the literature on the other. Whereas a substantial body of the literature has investigated the effect of financial reforms on financial development (Cho 1986; Arestis et al. 2002; Batuo et al. 2010), to the best of our knowledge, the literature on financial efficiency has been scarce. Moreover, the concept of financial efficiency has not been considered within the fundamental mission of banking institutions to transform mobilized deposits into credit for economic operators (Ataullah et al. 2004; Saxegaard 2006; Al-Obaidan 2008; Kiyota 2009; Kablan 2010). Some mainstream measurements of financial efficiency in Africancentric literature include cost efficiency (Chen 2009; Mensah et al. 2012), profit efficiency (Hauner and Peiris 2005), and data envelopment analysis (DEA) for technical 
efficiency (Kablan 2009). Kukenova (2011, p.1) has suggested this may be the principal hurdle in assessing the nexus between liberalization and allocation efficiency, which is traceable to the fact that capital allocation efficiency is not directly observable.

In light of the above arguments, the contribution of this study to the literature is twofold, notably (i) it defines, creates, and measures financial allocation efficiency on a continent with severe surplus liquidity in financial institutions and (ii) comparative analyzes of regionalization policies based on ongoing efforts for regional integration across the continent. First, our concept of efficiency is contrary to the two mainstream measurements of financial allocation efficiency, namely (i) the efficiency of decision making by means of $\mathrm{DEA}^{4}$ and (ii) overall economic efficiency (OEE) with regard to scale and technical efficiencies ${ }^{5}$ or profitability- and cost-related perspectives. ${ }^{6}$ Essentially, the conception of allocation efficiency in this study considers the ability of financial institutions to transform mobilized financial deposits into credit for economic operators. Hence, this measurement is consistent with the surplus liquidity in African financial institutions. Second, the study simultaneously contributes to the ongoing debate on the effects of globalization and the evolving literature stream on regionalization in Africa by assessing the effects of regionalization policies on financial allocation efficiency. To this end, the timing of regionalization policies is tailored to comparatively investigate whether regionalization has improved or reduced financial allocation efficiency.

The rest of the study is organized as follows. Section 2 discusses the theoretical underpinnings in light of the debates on financial allocation. The data and methodology are covered in Section 3. Section 4 presents the empirical results, while Section 5 concludes the paper with implications and future directions.

\section{Theoretical perspectives on the nexus between financial allocation efficiency and globalization}

In accordance with Asongu (2013b), the decision on whether to adopt integration/ liberalization to facilitate financial allocation efficiency and enjoy the benefits of regional/international risk sharing has been extensively debated in policy and academic circles. Essentially, there are two main theoretical arguments on the relevance of integration as a policy choice for developing nations in their attempts to benefit from capital allocation efficiency.

The first argument supports the rewards of "allocation efficiency" and relies heavily on the predictions of neoclassical growth models based on the seminal study of Solow (1956). According to the neoclassical growth model, liberalization and integration policies enable the efficient allocation of capital because resources

\footnotetext{
${ }^{4}$ The reader can refer to, among others, Ataullah et al. (2004), who have employed the DEA approach to assess the scale and technical efficiencies of financial institutions in Pakistan and India. Also see Kablan (2009).

${ }^{5}$ We invite the reader to consult Al-Obaidan (2008), who has employed a composite indicator for banking system efficiency in the Gulf to establish that openness improves technical efficiency.

${ }^{6}$ This is in accordance with the related literature on financial efficiency in Africa (Kiyota 2009; Kablan 2010). Four main variables on financial efficiency have been discussed in the literature (Demirguc-Kunt and Beck 2009). "They include: the ratio of bank deposits (which measures the extent to which savings can fund private credit), the net interest margin (which is the accounting value of a bank's net interest revenues as a share of its total assets), overhead cost (or the accounting value of the bank's overhead cost as a share of its total assets) and, cost/income ratio (which assesses overhead costs relative to revenues)" (Asongu 2013b, p.665). Whereas the last-three are related to profitability, the concept of efficiency is first used in this study.
} 
flow from developed countries characterized by capital abundance to developing countries that have scarce capital and rich labor. Moreover, the return of capital is low (high) in developed (developing) countries. The related literature is broadly consistent regarding the advantages that developing countries enjoy, namely the reduction of capital cost and improvements in investment and economic prosperity that ultimately enhance living standards permanently (see Fischer 1998; Obstfeld 1998; Rogoff 1999; Summers 2000; Batuo and Asongu 2015; Javid and Katircioglu 2017; Katircioglu and Zabolotnov 2019). Hence, arguments on the gains from "allocation efficiency" have been generally used by developing countries worldwide to justify their adoption of liberalization and regionalization policies over the past decades (Asongu 2014b).

The second argument is that allocation efficiency is a fanciful means to extend the gains from the international trade in commodities to the one in financial assets. Specifically, the predictions of allocation efficiency are apparent only in the absence of distortions from the free movement of capital. Hence, given the distortions experienced by developing countries during financial crises, there is inconsistency between the reality of liberalization policies and the theoretical predictions of the neoclassical model. Within this framework, some notable studies include provocative titles such as "Who needs capital account convertibility?" (Rodrik 1998) and "Why did financial globalization disappoint?" (Rodrik and Subramanian 2009). According to the narrative, the correlation between globalization and allocation efficiency is not apparent because of the costs due to recurrent financial crises, which far outweigh the potential benefits (Rodrik 1998).

Rodrik and Subramanian (2009) have documented that, in the wake of the recent subprime crisis, the arguments about the externalities of financial engineering generating substantial gains in developing countries are less plausible. According to this narrative, even without the financial crisis, it is increasingly evident at the international level that the rewards of integration/globalization/liberalization are not apparent. ${ }^{7}$ The narrative further maintains that the postulated gains in terms of higher investment and growth in less developed countries are hard to identify because countries that have been developing rapidly relied less on liberalization. Therefore, globalization policies have not smoothened consumption and reduced volatility as hypothesized. Another perspective argues that the rewards of globalization today are unpersuasive, speculative, and indirect (Asongu 2014b) and it is time for a new paradigm shift in liberalization policies because more globalization is not necessarily better (Asongu 2013b). In light of the above literature review, we investigate whether the policy of regionalization increases financial allocation efficiency.

\section{Data and methodology \\ Data}

Globalization, financial, and control variables

We assess economic and monetary regional panels using data from the Financial Development and Structure Database (FDSD) and African Development Indicators (ADI) of

\footnotetext{
${ }^{7}$ The position is still subject to debate. Some arguments are as follows. (i) Leung (2003) concludes that increasing external debts in developing countries is worsening business cycles; (ii) Mulwa et al. (2009) suggests that liberalization has not resulted in improved productivity and efficiency in developing countries; (iii) Kholdy and Sohrabian (2008) establish that financial globalization may be associated with negative governance externalities in developing countries; and (iv) Asongu et al. (2015b) conclude that globalizationdriven debts are reducing inclusive human development in African countries.
} 
the World Bank from 1980 to 2008. Financial variables are obtained from the FDSD, whereas macroeconomic variables are from ADI. Two financial allocation efficiency indicators are used, namely: (i) banking system efficiency measured by "banking system credit on banking system deposits" and (ii) financial system efficiency proxied by "financial system credit on financial system deposits." The allocation efficiency variables consider the ability of banks to transform mobilized deposits into credit for economic operators (Demirguc-Kunt et al. 1999; Demirguc-Kunt and Beck 2009; Asongu 2013a). It is important to note that formal banking institutions are included in the financial system efficiency measurement. Accordingly, financial system efficiency is the banking system's efficiency plus the efficiency of other financial institutions. The understanding of a financial system that embodies formal and semi-formal financial sectors is clarified in Appendix 1 (Tchamyou et al. 2019). As shown in Appendix 1, the financial system entails formal banks and a semi-informal financial sector consisting of specialized nonbank financial institutions and other non-bank financial institutions, with (i) formal banks and specialized non-bank financial institutions being licensed by the central bank and (ii) other non-bank financial institutions being legally registered but not licensed as financial institutions by the central bank and government. Not included in the definition of the financial system is the informal financial sector, largely consisting of informal banks not registered at the national level, although they can be registered as associations. The informal sector mostly entails savings collectors, savings and credit associations, and money lenders.

Three openness indicators are used, namely financial openness, trade openness, and globalization. Trade openness consists of three measurements: imports, exports and imports plus exports. Financial openness consists of foreign direct investment (FDI), private capital flows (PCF) and a composite index of the FDI and PCF. The globalization variable is the composite index of financial openness and trade openness. These composite indicators are using principal component analysis (PCA). The definitions and classification of variables in Appendices 2 and 3 are consistent with the recent openness and finance literature. The financial openness variables are in line with Lane and Milesi-Ferreti (2006) and Baltagi et al. (2009), while the composite financial and trade openness indicators are adopted from Gries et al. (2009) and Hanh (2010).

The selected control variables are consistent with the recent financial development literature, namely GDP growth, inflation, public investment, and foreign aid (Asongu 2014b). The relationship between economic growth and financial development has been substantially documented in the literature. First, a growing economy is linked to a reduced cost of financial intermediation because, inter alia, the availability of funds for productive investments and competition (Greenwood and Jovanovic 1990; Saint Paul 1992). This relationship has been further confirmed in the literature (Levine 1997, 2003a, 2003b). Second, both empirical (Boyd et al. 2001) and theoretical (Huybens and Smith 1999) views maintain that higher inflation levels are associated with less efficient, less active, and smaller financial institutions. Essentially, macroeconomic policies are conducive to low/stable inflation and higher investment levels have been documented to be associated with higher levels of financial development (Asongu 2014b). Third, a positive relationship between investment and financial development has also been established in the literature (Huang 2011). Fourth, the theoretical basis for the policies of development assistance towards developing countries is mitigating the investment- 
financing gap (Easterly 2005). However, from a practical standpoint, the impact of foreign aid on domestic financial development can also be negative if a substantial ratio of donor funds is: (i) siphoned by corrupt officials in recipients nations and then deposited in tax havens whose jurisdictions are traceable to the donor community and (ii) spent in donor countries.

The summary statistics and correlation matrices are shown in Appendices 4 and 5, respectively. From the summary statistics, the variables are comparable in terms of their means. Moreover, the substantial degree of variation in the standard deviations is an indication that reasonable linkages should be expected. Given that imports, exports, and trade openness are expressed in tens whereas some indicators are expressed as decimals, we define the dependent variables both as a ratio and percentage to account for this slight difference in denomination. Hence, banking system efficiency is shown as a ratio whereas financial system efficiency is presented as a percentage.

This variation in the definitions of the dependent variables does not affect their degrees of substitutions in Appendix 5, since the corresponding correlation coefficients on the two variables are: $98.50 \%$ (Panel A), 92.50\% (Panel B), 89.90\% (Panel C), and 94.20\% (Panel D) for the UEMOA, CEMAC, COMESA, and EAC respectively. ${ }^{8}$ Hence, the purpose of the correlation matrices is to avoid multicollinearity concerns. For financial development variables, this concern is not an issue because they are employed as dependent variables and it is addressed for openness variables by employing them in distinct specifications. Given that the specification consists of interactive regressions, contrary to linear additive models, multicollinearity is not an issue with interactive models (Brambor et al. 2006). This is essentially because the effect of the interactive policy variable of regionalization is considered a conditional marginal impact.

\section{Categorization of regions and determination of regionalization policy dummies}

As shown in Table 1, at the time of this study, there were 11 main economic and/or monetary regions in Africa, namely, the: Economic Community of West African States (ECOWAS), West African Economic and Monetary Union (UEMOA), Economic Community of Central African States (ECCAS), Economic and Monetary Community of Central Africa (CEMAC), Franc Zone (CEMAC plus UEMOA countries), ${ }^{9}$ South African Development Community (SADC), East African Community (EAC), South African Customs Union (SACU), Common Market for East and Southern Africa (COMESA), Intergovernmental Authority on Development (IGAD), and Arab Maghreb Union (UMA). The policy dummies are for the year when regionalization policies became effective.

ECOWAS, Franc Zone, SADC, SACU, IGAD, and UMA are not included in our analysis because data were either unavailable or limited for the application of a policy dummy-oriented fixed effects estimation technique with respect to their creation dates. For the remaining economic and/or monetary unions, as shown in Table 2, because of data availability constraints, the study narrowed the number of countries in the database to: (i) Benin, Ivory Coast, Mali, Niger, and Senegal are retained for UEMOA; (ii) Cameroon, Gabon, and the Congo Republic for CEMAC; (iii) Kenya, Tanzania, and

\footnotetext{
${ }^{8}$ UEMOA: West African Economic and Monetary Union; CEMAC: Economic and Monetary Community of Central Africa; COMESA: Common Market for Eastern and Southern Africa; EAC: East African Community. ${ }^{9}$ Whereas the WAEMU and CEMAC are within the Franc Zone, we can take a minimalist approach by also considering them as distinct economic/monetary zones because they have different central banks.
} 
Table 1 Presentation of regions with corresponding balanced panels

\begin{tabular}{|c|c|c|c|}
\hline Regions & $\begin{array}{l}\text { Definitions (Number of } \\
\text { member states) }\end{array}$ & Constituent countries(Founding dates) & $\begin{array}{l}\text { Panel/ } \\
\text { Dummy }\end{array}$ \\
\hline $\begin{array}{l}\text { ECOWAS } \\
(\text { CDEAO) }\end{array}$ & $\begin{array}{l}\text { Economic Community of } \\
\text { West African States. (15) }\end{array}$ & $\begin{array}{l}\text { Benin, Burkina Faso, Cape Verde(1976), Côte d'Ivoire, } \\
\text { Gambia, Ghana, Guinea, Guinea-Bissau, Liberia, Mali, Niger, } \\
\text { Nigeria, Senegal, Sierra Leone, Togo, Mauritania(2000). (5/ } \\
\text { 1975) }\end{array}$ & $\mathrm{N} / \mathrm{A}$ \\
\hline UEMOA & $\begin{array}{l}\text { West African Economic and } \\
\text { Monetary Union(8) }\end{array}$ & $\begin{array}{l}\text { Benin, Burkina Faso, Côte d'Ivoire, Guinea-Bissau (5/1997) }{ }^{a} \text {, } \\
\text { Mali, Niger, Senegal, and Togo. (1/1994) }\end{array}$ & $\begin{array}{l}(80- \\
08) / \\
(94-08)\end{array}$ \\
\hline $\begin{array}{l}\text { ECCAS } \\
(\text { UDEAC) }\end{array}$ & $\begin{array}{l}\text { Economic Community of } \\
\text { Central African States }(11)\end{array}$ & $\begin{array}{l}\text { Angola(1999) }{ }^{a} \text {, Burundi, Cameroon, Central African } \\
\text { Republic, Chad, D.R. Congo, Equatorial Guinea, Gabon, } \\
\text { Congo, Rwanda, Sao Tomé and Principe. (1985) }\end{array}$ & $\begin{array}{l}(90- \\
08) / \\
(99-08)\end{array}$ \\
\hline CEMAC & $\begin{array}{l}\text { Economic and Monetary } \\
\text { Community of Central } \\
\text { Africa(6) }\end{array}$ & $\begin{array}{l}\text { Cameroon, Central African Republic, Chad, Congo, } \\
\text { Equatorial Guinea, and Gabon. (1999) }\end{array}$ & $\begin{array}{l}(90- \\
08) / \\
(99-08)\end{array}$ \\
\hline $\begin{array}{l}\text { Franc } \\
\text { ZONE }\end{array}$ & CEMAC plus UEMOA (14) & $\begin{array}{l}\text { Cameroon, Central African Republic, Chad, Congo, } \\
\text { Equatorial Guinea, Gabon, Benin, Burkina Faso, Côte } \\
\text { d'lvoire, Guinea-Bissau, Mali, Niger, Senegal, and Togo(9/ } \\
\text { 1939) }\end{array}$ & $\mathrm{N} / \mathrm{A}$ \\
\hline SADC & $\begin{array}{l}\text { South African Development } \\
\text { Community (15) }\end{array}$ & 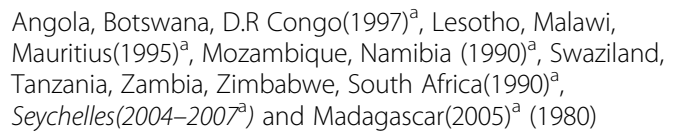 & $\mathrm{N} / \mathrm{A}$ \\
\hline SACU & $\begin{array}{l}\text { South Africa Customs } \\
\text { Union(4) }\end{array}$ & South Africa, Botswana, Lesotho and Swaziland. (1970) & N/A \\
\hline EAC & East African Community (5) & $\begin{array}{l}\text { Burundi (2007), Kenya, Rwanda (2007), Tanzania and } \\
\text { Uganda. (2001) }\end{array}$ & $\begin{array}{l}(90- \\
08) / \\
(02-08)\end{array}$ \\
\hline COMESA & $\begin{array}{l}\text { Common Market for Eastern } \\
\text { and Southern Africa (19) }\end{array}$ & $\begin{array}{l}\text { Burundi, Comoros, D.R Congo, Djibouti, Egypt(1999)a, } \\
\text { Eritrea, Ethiopia, Kenya, Libya(2006) }{ }^{a} \text {, Madagascar, Malawi, } \\
\text { Mauritius, Rwanda, Seychelles(2001) a , Sudan, Swaziland, } \\
\text { Uganda, Zambia, Zimbabwe.(1994) }\end{array}$ & $\begin{array}{l}(80- \\
08) / \\
(95-08)\end{array}$ \\
\hline IGAD & $\begin{array}{l}\text { Intergovernmental Authority } \\
\text { on Development (7) }\end{array}$ & $\begin{array}{l}\text { Djibouti, Ethiopia, Eritrea (1993) }{ }^{a} \text {, Kenya, Somalia, Sudan, } \\
\text { Uganda. (1986) }\end{array}$ & $\mathrm{N} / \mathrm{A}$ \\
\hline UMA & Arab Maghreb Union (5) & Algeria, Morocco, Tunisia, Libya, Mauritania (1989) & $\mathrm{N} / \mathrm{A}$ \\
\hline
\end{tabular}

Countries with dates in brackets are non-founding members. Countries in italics have withdrawn their membership. ${ }^{a}$ : countries not considered for panel because they entered the region very late or withdrew over time. N/A; denotes the region cannot be included in the study because creation date renders data incompatible with application of the adopted estimated technique. ${ }^{b}$ Founded in 1985 but became effective only by 1999 . Policy dummies are based on the year the regional body became effective. This is why the policy dummy for ECCAS is from 1999 though it was founded in 1985

Uganda constitute the EAC; and (iv) Burundi, Kenya, Madagascar, Mauritius, Malawi, Rwanda, Sudan, Swaziland, Uganda, and Zambia for COMESA.

In the ECCAS, Burundi, Cameroon, the Congo Republic, Gabon, and Rwanda are selected. However after analysis, we are unable to check for robustness because the financial efficiency indicator used to assess the banking efficiency proxy has a different integration degree. $^{10}$

The policy dummies are adopted from the year these regional bodies came into force in the respective countries. As these are called "time policy dummies," they are indeed country-specific and contingent on the time the countries adopted the common treaty in the regional body relative to the full sample. For instance, for Kenya, the sample for the EAC is from 1990 to 2008 while the policy dummy is used from 2001 to 2008 . This

\footnotetext{
${ }^{10}$ From an empirical viewpoint, the high correlation (88\%) between banking and financial system efficiency for ECCAS is a necessary but insufficient condition for robustness testing. The compatibility of integration orders in endogenous variables is also crucial for the robustness check.
} 
Table 2 Selected regions and countries

\begin{tabular}{|c|c|c|c|}
\hline Regions & Selected countries & Panels & $\begin{array}{l}\text { Policy } \\
\text { Dummies }\end{array}$ \\
\hline UEMOA & Benin, Ivory Coast, Mali, Niger and Senegal & $\begin{array}{l}1980- \\
08\end{array}$ & $1994-08$ \\
\hline COMESA & $\begin{array}{l}\text { Burundi, Kenya, Madagascar, Mauritius, Malawi, Rwanda, Sudan, Swaziland, } \\
\text { Uganda, Zambia }\end{array}$ & $\begin{array}{l}1980- \\
08\end{array}$ & 1995-08 \\
\hline CEMAC & Cameron, Gabon, Congo Republic & $\begin{array}{l}1990- \\
08\end{array}$ & 1999-08 \\
\hline ECCAS & Burundi, Cameroon, Congo Republic, Gabon, Rwanda & $\begin{array}{l}1990- \\
08\end{array}$ & 1999-08 \\
\hline EAC & Kenya, Tanzania, Uganda & $\begin{array}{l}1990- \\
08\end{array}$ & 2002-08 \\
\hline
\end{tabular}

UEMOA: West African Economic and Monetary Union. CEMAC: Central African Economic and Monetary Community. COMESA: Common Markets for Eastern and Southern Africa. EAC: East African Community. We dropped ECCAS because of incompatibility of robustness test. The Panel column represents the full sample whereas the policy dummy column denotes the year a common regional treaty was adopted for the sampled countries

is not the case for the COMESA, which has a full sample from 1980 to 2008 and the policy dummy starts from 1994. Hence, the full samples for the two regions as well as the time the regional treaties were adopted differ, which justifies the differences in the adopted policy dummies. Hence, the policy dummies are region-specific and start from the year the regional treaties were adopted. Moreover, the policy dummy may be for the same year as the year the regional treaty was adopted or a year ahead depending on the adoption date. For instance, only the following year is considered if a treaty is adopted late in a given year. In other words, if a treaty is adopted in December 2000, the policy dummy begins in 2001, while if a treaty is adopted in January 2000, the policy dummy begins in 2000 .

\section{Methodology}

\section{Principal component analysis}

Given the high degree of substitution between the globalization variables, our methodology is consistent with the recent literature employing PCA to derive composite indicators (Andrés et al. 2015; Tchamyou 2017; Asongu and Nwachukwu 2016a). PCA is a widely used technique to reduce a set of highly correlated variables to a smaller set of uncorrelated indicators called principal components (PCs), which represent a substantial proportion of the information or variability in the constituent indicators. The criterion used to decide which information to retain is adopted from Jolliffe (2002) and Kaiser (1974), who have recommended that PCs with an eigenvalue greater than the mean or 1 should be retained.

Table 3 shows the derivation of the composite indices. The eigenvalues and corresponding variations of first retained PCs are consistent with the criterion above. For example, the financial globalization indicator (Finopex) in Panel A for the UEMOA region, which consists of FDI and PCF, has an eigenvalue of 1.898 and accounts for about $94.9 \%$ of the information in the constituent indicators. Finopex is the financial openness index and the first PC of foreign direct investment and private capital flows while Globex is the globalization index and is the first PC of Finopex and trade openness. Trade openness consists of imports plus exports (i.e., I $+\mathrm{X}$ ). The linear combinations are provided in the component matrix in Table 3 and the constituting variables 
Table 3 Derivation of Indices (Financial Openness and Globalization indices)

\begin{tabular}{|c|c|c|c|c|c|c|}
\hline \multirow{2}{*}{$\frac{\text { Principal Indicator }}{\text { Panel A: UEMOA }}$} & \multirow[t]{2}{*}{ Indexes } & \multirow[t]{2}{*}{ Cor. coef. (t-stats) } & \multirow[t]{2}{*}{ Eigen Value } & \multirow[t]{2}{*}{ First PC variation } & \multicolumn{2}{|c|}{ Component Matrix } \\
\hline & & & & & & \\
\hline \multirow[t]{2}{*}{ Financial Openness } & Finopex & $0.898^{* * *}$ & & & FDlgdp & PCFgdp \\
\hline & & $(23.53)$ & 1.898 & 0.949 & 0.707 & 0.707 \\
\hline \multirow[t]{2}{*}{ Globalization } & Globex & $0.199^{* *}$ & & & Finopex & $(I+X) g d p$ \\
\hline & & $(2.34)$ & 1.199 & 0.599 & 0.707 & 0.707 \\
\hline \multicolumn{7}{|l|}{ Panel B: COMESA } \\
\hline \multirow[t]{2}{*}{ Financial Openness } & Finopex & $0.981^{* * *}$ & & & FDlgdp & PCFgdp \\
\hline & & $(82.51)$ & 1.981 & 0.990 & 0.707 & 0.707 \\
\hline \multirow[t]{2}{*}{ Globalization } & Globex & $0.250^{* * *}$ & & & Finopex & $(I+X) g d p$ \\
\hline & & $(4.15)$ & 1.250 & 0.625 & 0.707 & 0.707 \\
\hline \multicolumn{7}{|l|}{ Panel C: CEMAC } \\
\hline \multirow[t]{2}{*}{ Financial Openness } & Finopex & $0.994^{* * *}$ & & & FDlgdp & PCFgdp \\
\hline & & $(64.94)$ & 1.994 & 0.997 & 0.707 & 0.707 \\
\hline \multirow[t]{2}{*}{ Globalization } & Globex & $0.360^{* *}$ & & & Finopex & $(I+X) g d p$ \\
\hline & & $(2.58)$ & 1.360 & 0.680 & 0.707 & 0.707 \\
\hline \multicolumn{7}{|l|}{ Panel D: EAC } \\
\hline \multirow[t]{2}{*}{ Financial Openness } & Finopex & $0.996^{* * *}$ & & & FDlgdp & PCFgdp \\
\hline & & (88.912) & 1.996 & 0.998 & 0.707 & 0.707 \\
\hline \multirow[t]{2}{*}{ Globalization } & Globex & $-0.352^{* * *}$ & & & Finopex & $(I+X) g d p$ \\
\hline & & $(-2.744)$ & 1.352 & 0.676 & -0.707 & -0.707 \\
\hline
\end{tabular}

Globex: Globalization Index. Finopex: Financial Openness Index. FDIgdp and PCFgdp are capital account openness indicators. $(I+X) g d p$ is the trade openness variable. PC: Principal Component. Cor. Coef: Correlation coefficient. ${ }^{*}, *^{*}, *^{* *}$ : are respectively $10 \%, 5 \%$ and $1 \%$ significance levels

have equal weights on the corresponding PCs. "The paper uses PCA because we aim to reduce the observed correlated variables into a smaller set of independent and/or uncorrelated composite variables. In other words, we wish to extract linear composites of observed variables. Factor analysis is inappropriate because we are not testing a theoretical model of latent factors causing observed variables. Accordingly, it is consistent with the test for a theoretical model of latent factors causing observed variables" (Asongu 2017, p. 90).

It is important to discuss the statistical relevance of PC-derived globalization indicators. These can be engaged at two levels, namely general and specific (Asongu and Nwachukwu 2016b). First, from a general perspective, Pagan (1984, p. 242) has documented concerns that could arise when regressors are obtained from initial estimations related to the efficiency, consistency, and inferential validity of the estimated parameters. Whereas two-step estimators are reliable when it comes to consistency and efficiency, few valid inferences may be provided by the underlying estimates. The concern about inferential validity has been confirmed by a stream of studies (Oxley and McAleer 1993; Ba and Ng 2006; McKenzie and McAleer 1997; Westerlund and Urbain 2013a).

Second, from the specific angle, we are employing PC indicators. Concerns about PC-derived variables have been documented by Westerlund and Urbain (2012, 2013b), who have built on the previous works cited in the preceding paragraph, as well as Stock and Watson (2002); Pesaran (2006), Bai (2003, 2009), and Greenaway-McGrevy et al. 
(2012). The authors have cautioned that normal inferences can be made if PC-factor augmented estimators converge towards their values at the rate of $\sqrt{T N}$, where $\mathrm{N}$ represents cross-section observations and $\mathrm{T}$ denotes the number of time series. Furthermore, Westerlund and Urbain (2012, 2013b) have argued that the conditions for convergence required good inferences from PC-derived estimators and are more feasible when the sample is relatively large. Unfortunately, the authors have not disclosed how large. Concerning the sample used in the study, we can neither extend $\mathrm{T}$ nor $\mathrm{N}$ for two reasons. First, the $\mathrm{N}$ selected for the sampled economic and monetary regions is based on data availability. Accordingly, economic regions have a limited number of countries by definition. Second, the adopted time series is tailored to increase $\mathrm{T}$ as much as possible. Essentially, the policy time dummies are from the year when regionalization policies became effective. In addition, Asongu and Nwachukwu (2016b) have recently concluded on the feasibility of inferences from PC-augmented regressors using sub-samples that are comparatively lower in terms of $\mathrm{T}$ and $\mathrm{N}$ values.

\section{Estimation technique}

There is an abundant literature supporting the choice of an estimation technique as contingent on the objective of the study and behavior of corresponding data (Kou et al. 2012, 2014, 2016, 2019a, 2019b; Li et al. 2014, 2016; Zhang et al. 2019; Chao et al. 2019). Therefore, the choice of the estimation technique is contingent on both the objective of the study and the behavior of data in this study. As previously mentioned, the objective of this study is to assess post-regionalization policy effects. This requires the application of policy-time dummies, which is by definition consistent with a fixed effects (FE) regression. The economic relevance of a FE regression is that it accounts for the unobserved heterogeneity in sub-samples. In the panel data analysis, the FE estimator is also called a "within estimator" and there exists an assumption of time independent impacts for every country that is potentially correlated with the regressors.

Moreover, FE regressions have the added advantage of not hypothetically assuming the explanatory variables are uncorrelated with residuals. Furthermore, the use of FE accounts for the unobserved heterogeneity between the countries in the region. Generally, in the literature, when a panel consists of observations on a fixed and relatively small sets of interest units (e.g., member states of a given region), there is a presumption in favor of country FE.

Despite this intuition for a FE estimator, we still employ the Hausman test to assess if the intuition for the estimation technique is consistent with the data behavior. Regarding whether ordinary least squares (OLS) with FE or generalized least squares (GLS) with FE should be applied, we opt for the latter and justify our choice by testing for the significance of heteroscedasticity.

The adopted estimation is:

$$
F E_{i, t}=\alpha_{0}+\sigma_{1} G_{i, t}+\sigma_{2} P_{i, t}+\sigma_{3} G P_{i, t}+\sum_{h=1}^{4} \delta_{h} W_{h, i, t}+\eta_{i}+\varepsilon_{i, t},
$$

where $F E_{i, t}$ is either the banking system efficiency or financial system efficiency of country $i$ in period $t ; G_{i, t}$ is a globalization indicator (imports, exports, trade openness, 
private capital flows, foreign direct investment, financial globalization (Finopex) and globalization (Globex)); $P_{i, t}$ is a regionalization policy variable that may either take 0 (before regionalization) or 1 (after regionalization); $P G_{i, t}$ is the interaction term between globalization and the regionalization policy variable; $\alpha_{0}$ is a constant; $W$ is the vector of control variables (GDP growth, inflation, public investment and foreign aid); $\eta_{i}$ is a country-specific effect; and $\varepsilon_{i, t}$ the error term. The specifications are heteroscedasticity and autocorrelation consistent (HAC) in standard errors. Moreover, specifications are tailored to avoid the potential issues of multicollinearity associated with globalization indicators.

\section{Empirical results}

\section{Presentation of results}

Tables 4 and 5 present estimated results. Whereas Table 4 discloses findings on the UEMOA (Panel A) and CEMAC (Panel B), Table 5 shows results for the COMESA (Panel A) and EAC (Panel B). Each panel consists of two sets of specifications, namely regressions with banking system efficiency on the left-hand side (LHS) and estimations with financial system efficiency on the right-hand side (RHS).

The following can be established from Panel A of Table 4 for the UEMOA. First, whereas the effects of imports, exports, trade openness, and globalization are positive on banking system efficiency, the marginal effects from the interaction with regionalization are negative. This is evidence of decreasing returns to allocation efficiency from globalization-fueled regionalization. Hence, it can be inferred that the effect of regionalization is likely to exhibit a Kuznets or inverted U-shaped curve because the unconditional globalization estimates are positively significant, whereas the conditional effects based on an interaction with regionalization policy are negative. This is supported by the unconditional negative effect of regionalization policy. Second, most significant control variables have the expected signs. Third, the findings for financial system efficiency on the RHS are consistent with those for banking system efficiency on the LHS. Fourth, the Hausman test confirms the data behavior is consistent with the intuition for adopting a FE regression technique because the null hypothesis which is the position of random effects (RE) or between estimators is overwhelmingly rejected.

In Panel B of the same table, for the CEMAC region, (i) unconditional regionalization variables have negative effects on allocation efficiency, (ii) the marginal effect of globalization is negative on the LHS, (iii) most significant control variables display expected signs, and (iv) the Hausman test does not validate the choice of a FE estimator.

We clarify two concerns: the negative effect from GDP growth and the relevance of a threshold effect for the existence of a Kuznets curve from globalization on the LHS even when the unconditional effect from globalization is not significant. First, the negative impact of GDP growth can be traceable to the lack of broad-based growth in Africa. Whereas prior to the mid-1990s, the growth experienced by the continent was low, the recent period of growth resurgence that began in the mid-1990s (Fosu 2015) has been immesirizing because, from the mid-1990s, the extreme poverty has been decreasing in all regions of the world with the exception of Africa (Tchamyou 2019a, 2019b; Tchamyou et al. 2019). 


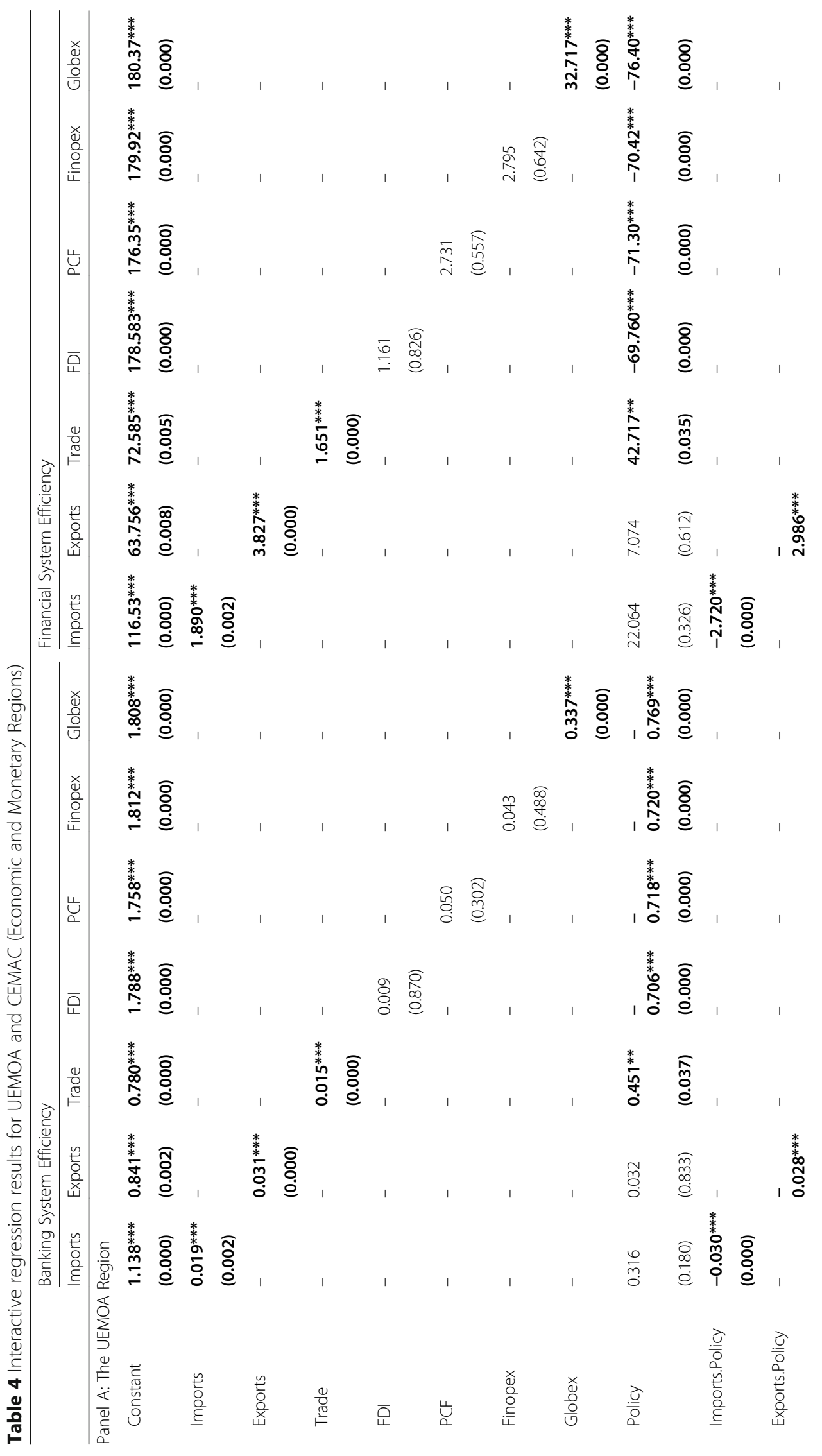




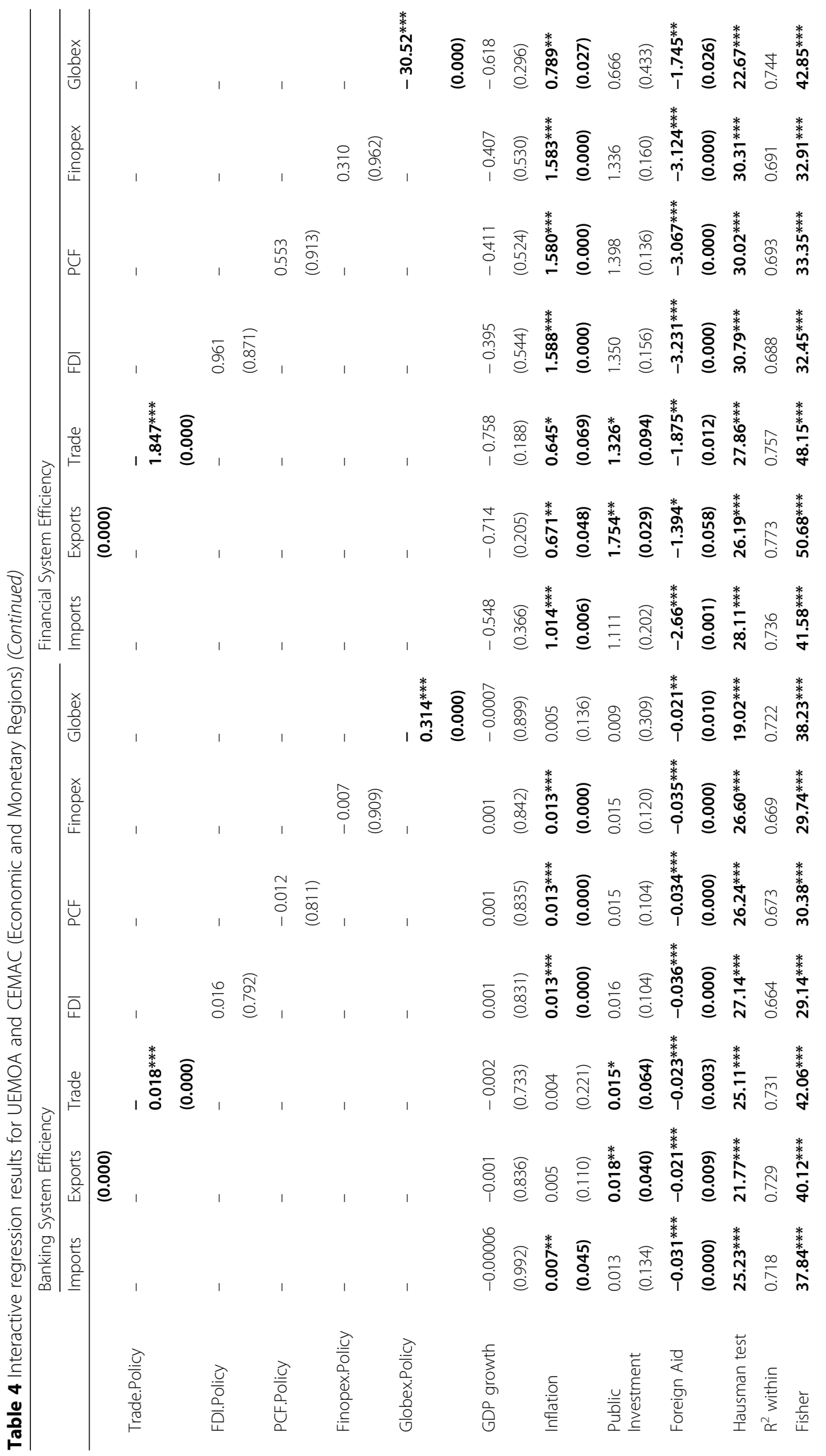




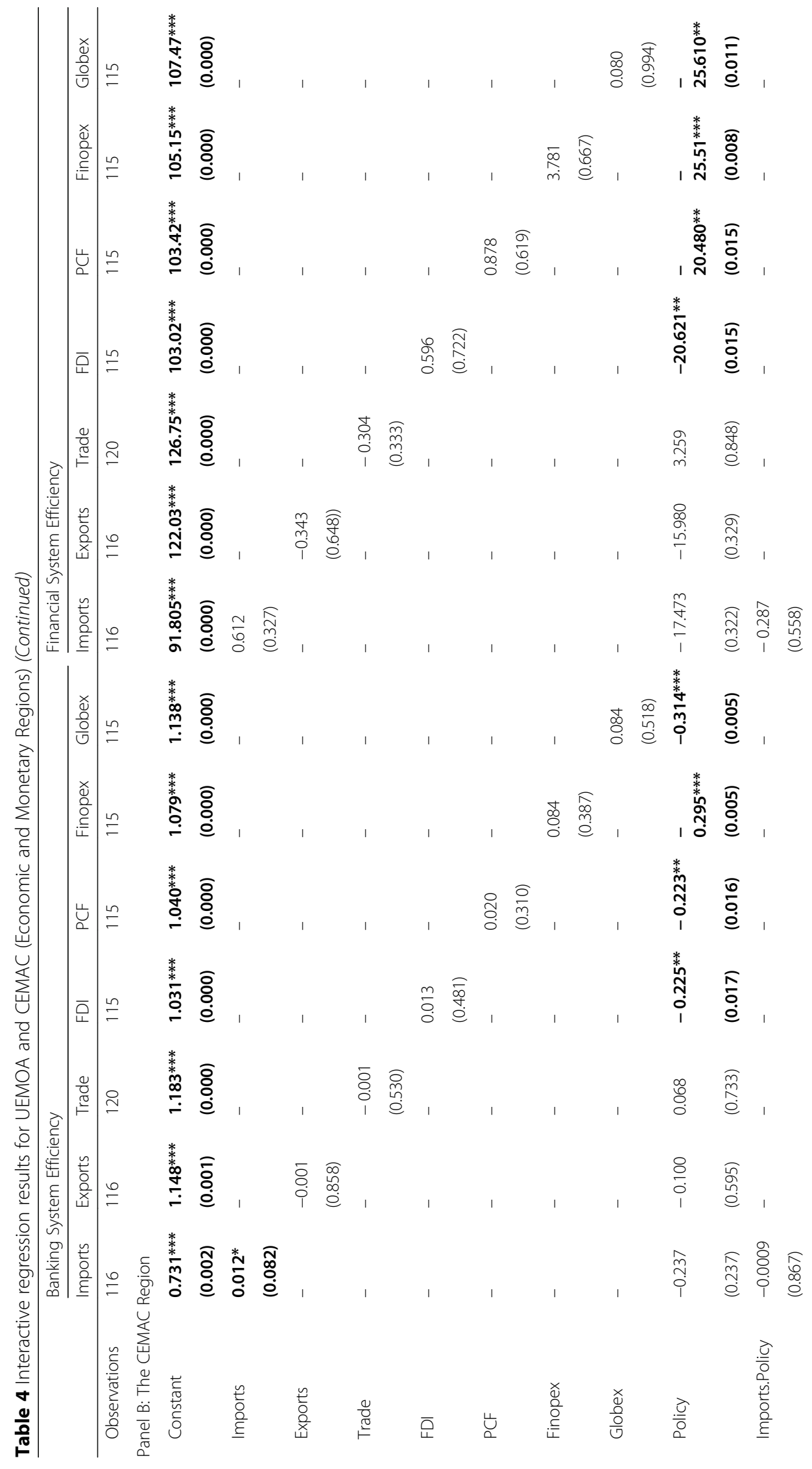




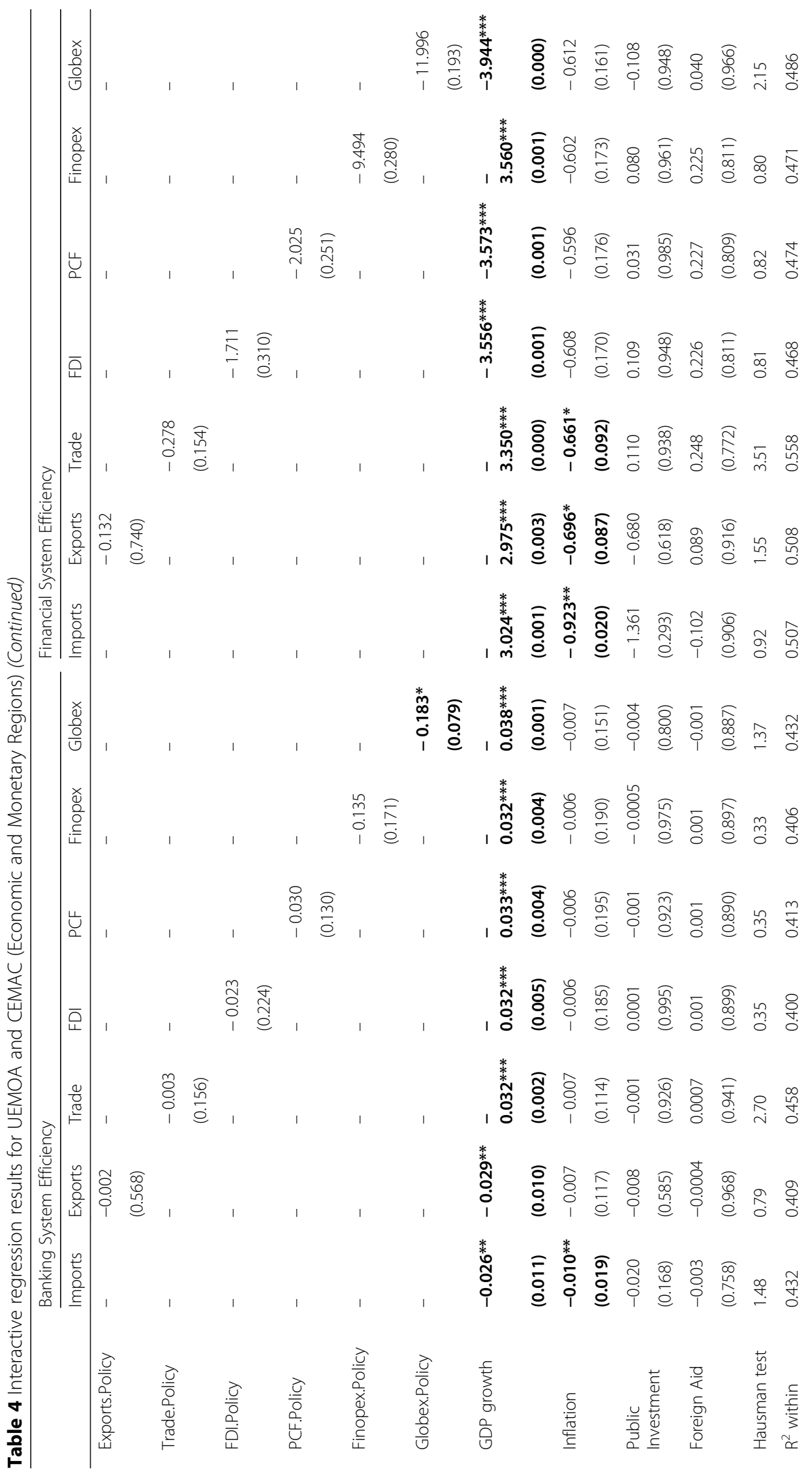




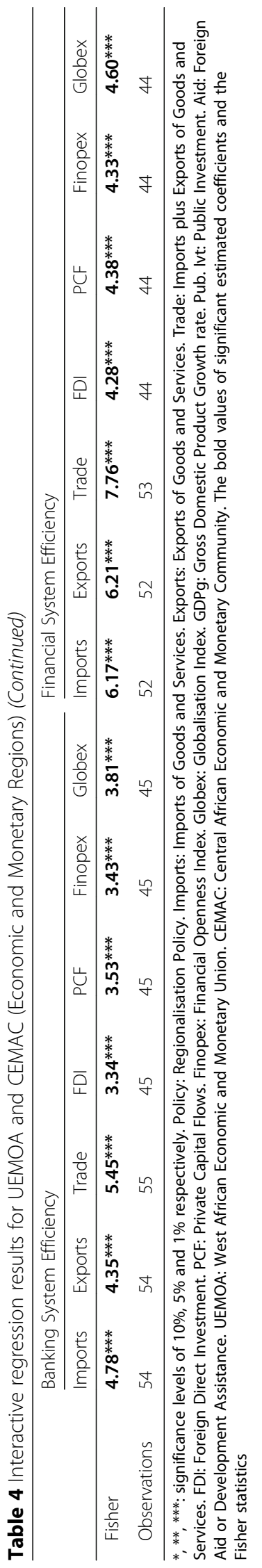




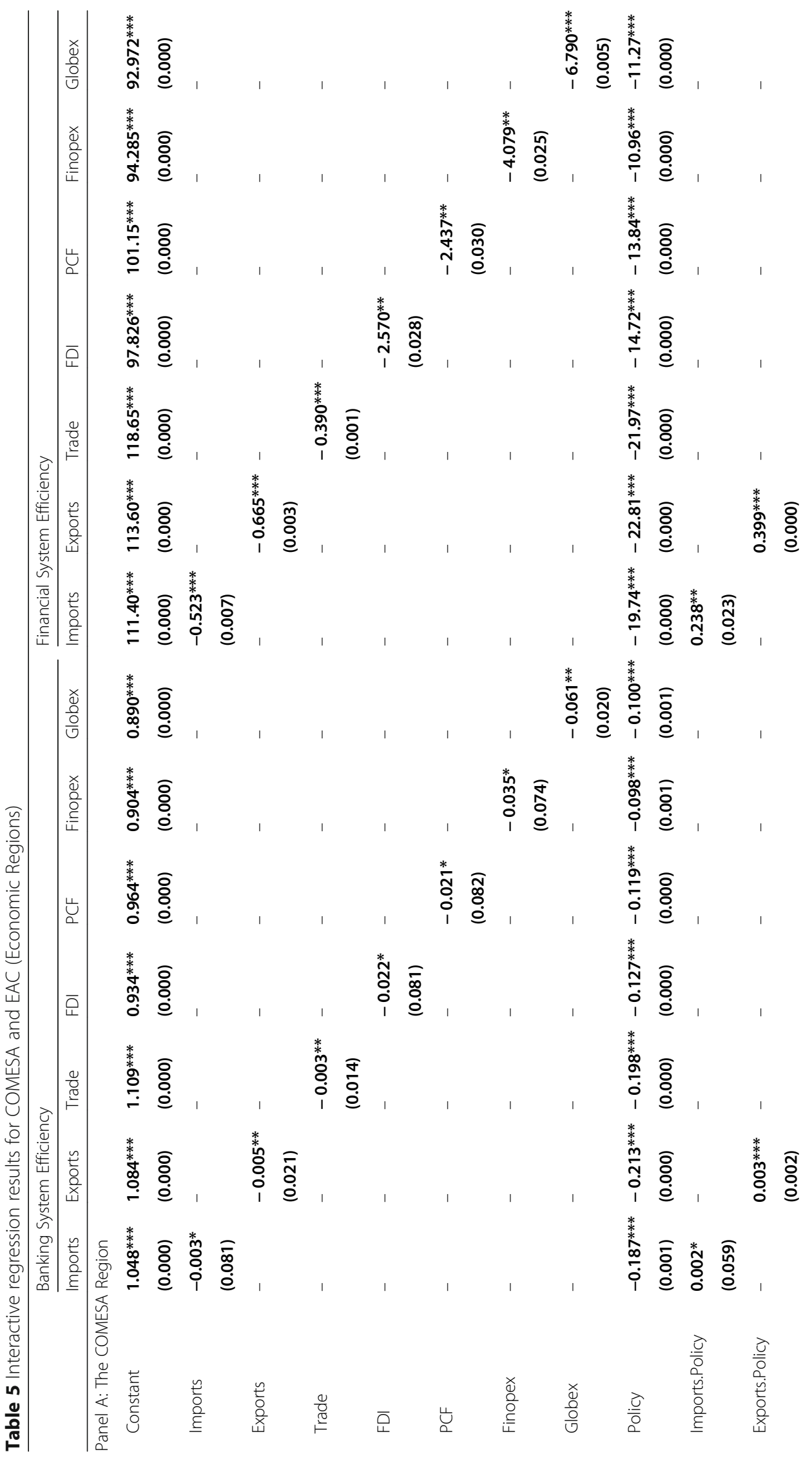




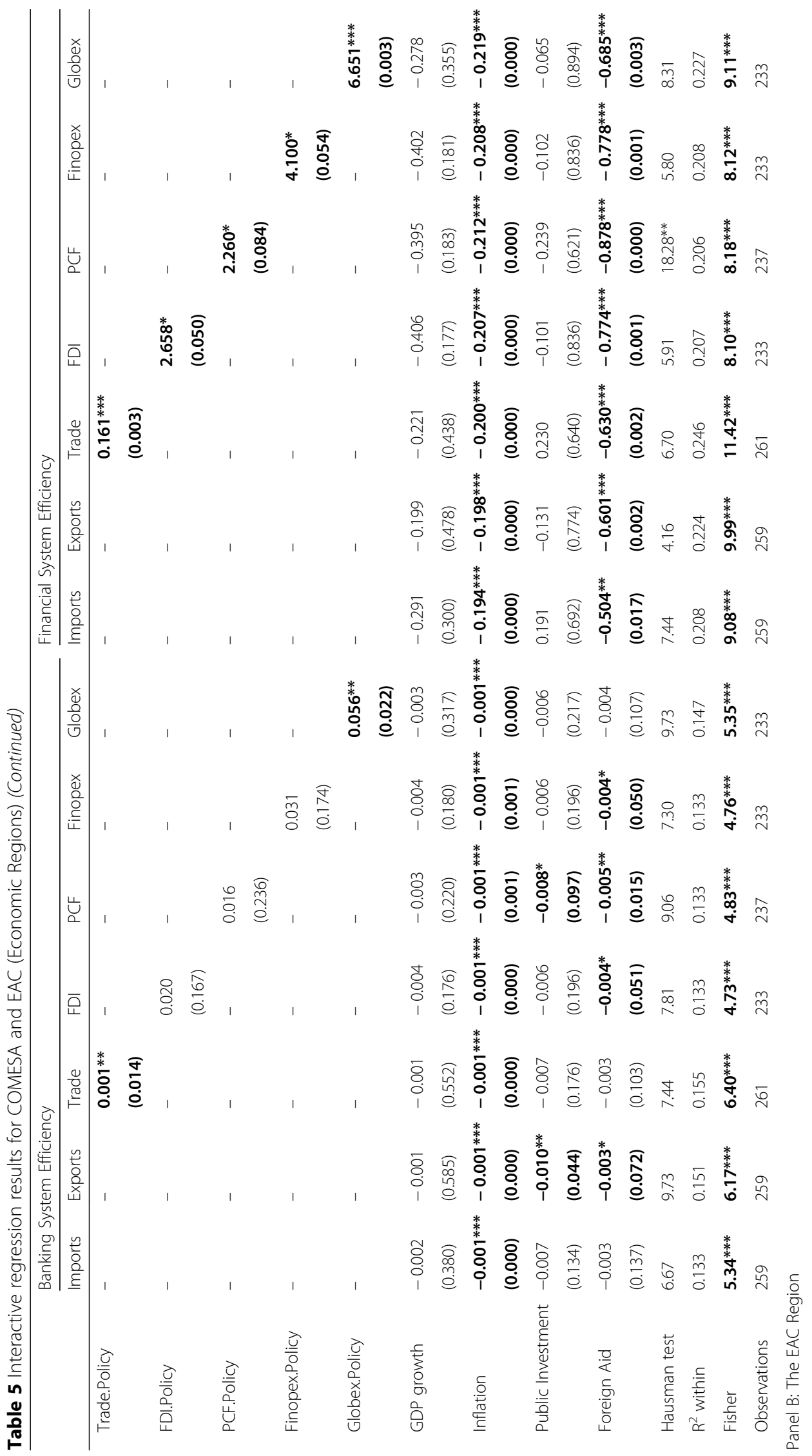




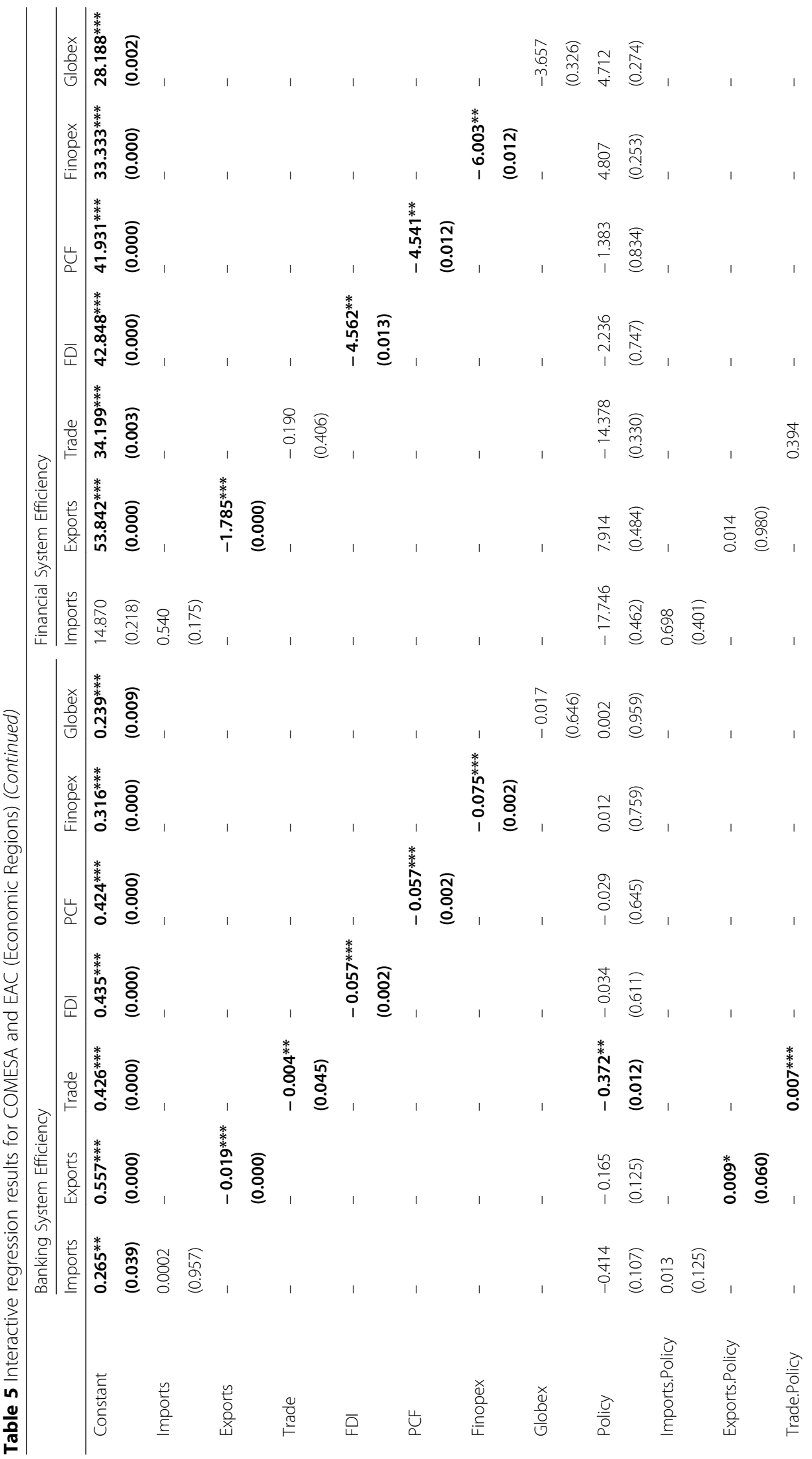




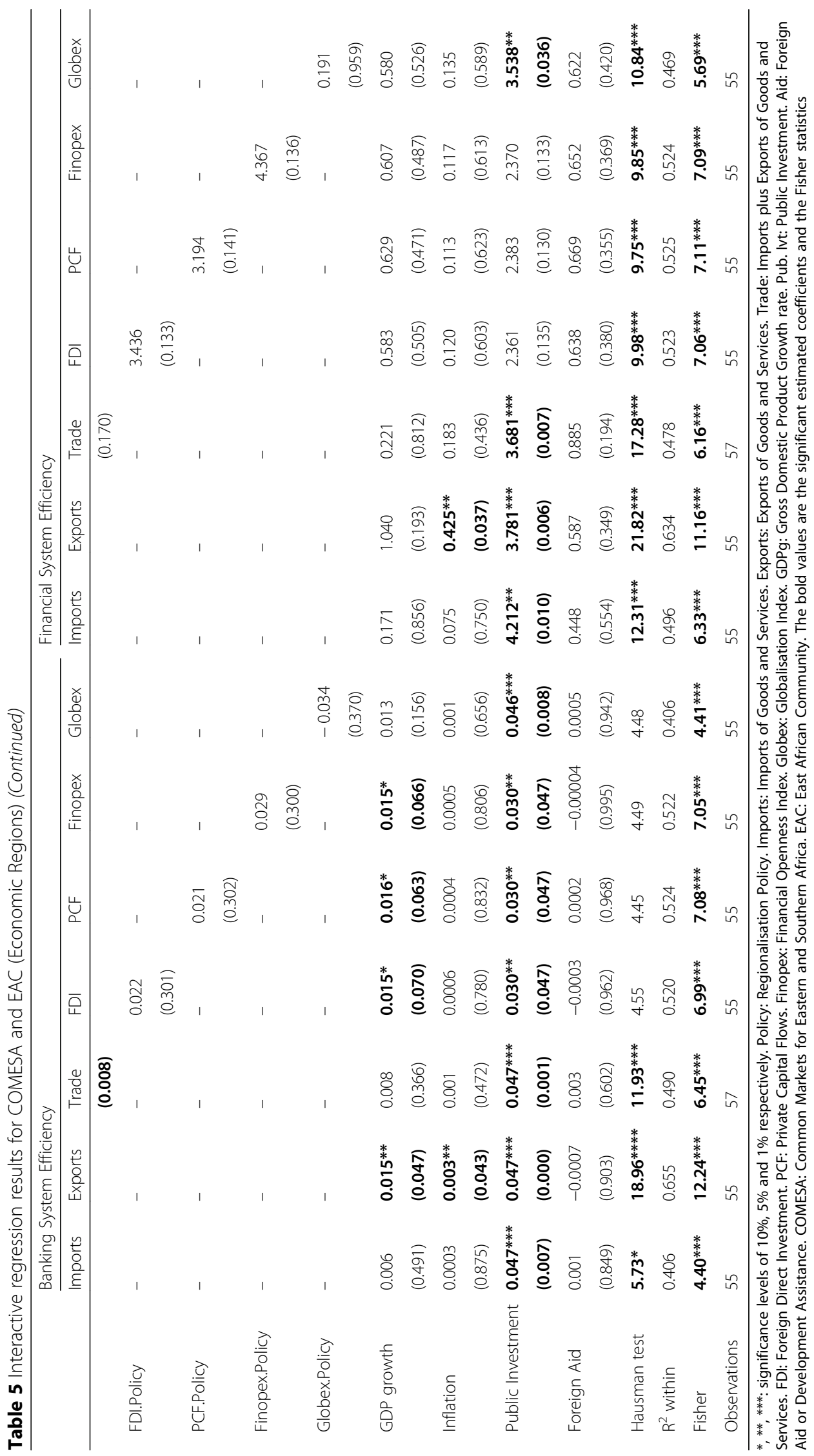


Second, the notion of threshold is in accordance with Cummins' (2000) minimum level of language proficiency before a second-language speaker can begin reaping the benefits from a given language. Moreover, the definition of threshold is also consistent with the critical mass theory in economic development studies (e.g., Roller and Waverman 2001; Ashraf and Galor 2013). Batuo (2015) and Asongu and Odhiambo $(2019 \mathrm{a}, \mathrm{b})$ have recently applied the threshold or critical mass theory using interactive variables. Therefore, within the framework of this research, the notion of threshold is consistent with the (i) critical mass for positive/negative effects (Roller and Waverman 2001; Batuo 2015), (ii) minimum requirement for enjoying of positive/negative effects (Cummins 2000), and (iii) criteria for Kuznets and U shapes (Ashraf and Galor 2013).

In the interactive regressions, when the unconditional effect is positive and the corresponding interactive or conditional effect negative, an inverted U-shaped nexus can be established. Conversely, when the unconditional effect is negative and the corresponding interactive or conditional effect positive, a U-shaped nexus can be established (see Ashraf and Galor 2013; Asongu and Kodila-Tedika 2018).

In Table 5, for the COMESA and EAC, the following findings are apparent. First, for the COMESA region, while the regionalization policy coefficient is consistently negative, the marginal effects from interaction with globalization are (i) positive from trade globalization and globalization on the LHS and (ii) positive from all globalization estimates on the RHS. This finding is consistent with the significant estimates from exports and trade openness on the LHS of Panel B for the EAC. It follows that the relationship between banking efficiency and globalization-fueled regionalization is likely to be U-shaped for the COMESA and EAC. Third, the significant control variables display the expected signs for the most part.

\section{Robustness checks}

We employ an alternative estimation technique to assess the robustness of the above findings. This new technique is different from that used in creating Tables 4 and 5 from three perspectives: (i) the after-policy and full sample estimates are directly compared to assess the effect of regionalization, (ii) regressions are based on consistency in the degree of integration from unit root tests, and (iii) dependent variables are both expressed as ratios. Appendices 6, 7 and 8 present the unit root tests, UEMOA and CEMAC, and COMESA and EAC findings, respectively.

The purpose of the panel unit test is to ensure that variables with the same degree of integration (for the most part) within an economic or a monetary region are used in estimations. It is essentially to control for this factor that the ECCAS region in Table 2 has not been further retained because the corresponding dependent variables do not have the same order of integration.

The choice of both homogenous (Levin et al. 2002) and heterogeneous (Im et al. 2003) panel unit tests is consistent with Hanh (2010). Following Liew (2004), the optimal lag selection for LLC and IPS tests are determined by the Hannan-Quinn information criterion (HQC) and Akaike information criterion 
(AIC), respectively. ${ }^{11}$ The results are presented in Appendix 6, with the variables without unit roots (stationary) in bold. In accordance with Asongu (2014c), the IPS test is given priority in the event of a conflict of interest. ${ }^{12}$

The following can be established after comparing the results of the findings in Tables 4 and 5 with those of Appendices 7 and 8. First, from Appendix 7, (i) results on the LHS for UEMAO on a potential Kuznets shaped curve are confirmed because the afterpolicy estimates have negative magnitudes, while the estimates for the whole sample are positive and (ii) the findings on the RHS for the CEMAC overwhelmingly confirm the previously scanty evidence of a Kuznets shaped curve. Second, from Appendix 8, the results for COMESA on a potential U-shaped curve are confirmed because the after-policy estimates have (i) negative magnitudes of lower negative order, while the corresponding estimates for the whole sample are negative with a higher order of negative magnitude, and (ii) positive magnitudes, while corresponding estimates for the whole sample are negative. This idea of a positive threshold based on decreasing negative magnitude is consistent with Asongu (2014b). The results for the EAC are not significant.

\section{Further discussions and implications}

This section discusses five main strands, namely the sensitivity of globalization dynamics, insights into the Rajan and Zingales (2003) hypothesis, increasing marginal effects, decreasing marginal impacts, and policy tools for reducing the surplus liquidity in African financial institutions.

First, financial allocation efficiency is shown to be more sensitive to financial openness compared to trade openness and most sensitive to globalization. This somewhat reflects the narrative in the literature of a less negative impact of trade openness on financial development compared to financial openness. Essentially, despite some consensus in the literature on the beneficial effects of trade globalization, the impact of financial globalization on financial development remains the object of heated debates (Asongu 2014b).

Second, contrary to the Rajan and Zingales (2003) hypothesis, which stipulates that the beneficial effects of globalization on financial development are more apparent when trade and capital accounts are liberalized simultaneously, our results are consistent with those of Baltagi et al. (2009) and Hanh (2010) in partially rejecting the underlying hypothesis. Hence, we establish that trade openness and financial openness are independent and significant determinants of bank sector efficiency or inefficiency.

Third, the increasing marginal effects of globalization-fueled regionalization on financial allocation efficiency in the COMESA substantiates the stream of literature that has confirmed the importance of openness in financial development (Kandiero and Chitiga 2003; Mbabazi et al. 2008; Kim et al. 2010). This includes African-specific studies on the importance of regional integration in the stock (Okeahalam 2001; Irving 2005;

\footnotetext{
${ }^{11}$ While the AIC and final prediction error (FPE) more efficiently estimate lags when observations are 60 or above, the HQC best avoids the underestimation of lags when observations are 120 and above. It is important to note that the LLC is based on pooled data. The Schwarz information criterion (SIC) also known as the Bayesian information criterion (BIC) presents the shortcoming of underestimating lags in the autoregression process.

${ }^{12}$ As articulated by Maddala and Wu (1999), the alternative hypothesis of the LLC test (on the absence of a common unit root) is strong.
} 
Yartey and Adjasi 2007) and financial intermediary markets (Wakeman-Linn and Wagh 2008).

Fourth, increasing marginal effects support the views of the literature strand that argues regionalization has not increased banking competitive pressures to the benefit of regional banks (Claessens et al. 2001; Peria et al. 2003; Shumkler 2004). According to this argument, regionalization from a financial viewpoint faces increased asymmetric information, which remains an important concern for lenders (banks) who might not always have good knowledge of what economic operators intent to do with borrowed funds, especially if the project/activity is to be implemented across national borders. This has greatly affected intermediation efficiency because savings are not fully exploited by the financial institutions. This discourse also aligns with the literature stream suggesting that some initial conditions may be essential to materialize the financial development benefits from globalization (Henry 2007; Kose et al. 2011; Asongu 2014b). As a policy implication, public information sharing offices such as public credit registries and private credit bureaus contribute to reducing information asymmetry and prove relevant initial conditions for the rewards in financial allocation efficiency from globalization-fueled regionalization policies.

It is reasonable to infer that while for UEMOA and CEMAC globalization-fueled regionalization has decreased the ability of the financial intermediary sector to provide funds for investment projects, COMESA has experienced the opposite effect, while the findings for the EAC are inconclusive or insignificant. It follows that regionalization has not been instrumental in financial intermediary efficiency over the past decades for the most part. Hence, our results reveal that economic and monetary regions have more surplus liquidity than pure economic regions. Therefore, the impact of globalization may be more detrimental to economic and monetary regions (UEMOA and CEMAC) than to purely economic regions (COMESA and EAC). ${ }^{13}$ This inference is consistent with the documented issues of surplus liquidity in the FCFA (Saxegaard 2006; Fouda 2009) and the recent findings of Price and Elu (2014), who have shown that African countries within the FCFA zone have been more likely to experience credit contraction during the recent financial crisis. Moreover, central banks in the FCFA focus on fighting inflation, which has led to low credit access and surplus liquidity in the attendant countries compared to other African countries that have preferred monetary experience to monetary stability pertaining to the use of a common currency (Asongu 2013c).

Fifth, consistent with Asongu (2014a, p. 70), we provide policy directions on how to fight surplus liquidity in the sampled countries. Essentially, the holding of excess cash could be either voluntary or involuntary. First, involuntary holding of surplus liquidity can be mitigated by (i) reducing the lending inability of banks, especially in scenarios of regulated interest rates; (ii) providing an enabling environment that encourages the spread of reserves and bonds to enable commercial banks to invest surplus cash in bond markets; (iii) establishing mechanisms that reduce information asymmetry and enhance competition to limit the

\footnotetext{
${ }^{13}$ If we increase the significance level for the EAC, the sign-effect of the globalization parameter satisfies this inference.
} 
unwillingness of financial institutions to lend; and (iv) developing regional stock markets that contribute to availing more investment opportunities to commercial banks. Second, the voluntary holding of surplus liquidity can be reduced by (i) easing constraints financial institutions face in tracking their positions within central banks, which may ultimately require them to hold cash above statutory limits; (ii) consolidating institutions that are favorable to interbank lending to facilitate interbank borrowing for contingency; and (iii) improving infrastructure so that bank branches in remote areas are not obliged to hold excess cash because of logistical and infrastructural issues.

\section{Conclusion and future research directions}

This study assesses the role of globalization-fueled regionalization policies on financial allocation efficiency in four economic and monetary regions in Africa from 1980 to 2008. Banking and financial system efficiency proxies are used as dependent variables, whereas seven bundled and unbundled globalization variables are employed as independent indicators. The bundling is achieved by means of PCA, while the empirical evidence is based on interactive fixed effects regressions. The findings are as follows. First, financial allocation efficiency is more sensitive to financial openness compared to trade openness and most sensitive to globalization. The relationship between allocation efficiency and globalizationfueled regionalization policies is represented by (i) a Kuznets or inverted Ushaped relationship in the UEMOA and CEMAC (evidence of decreasing returns to allocation efficiency from globalization-fueled regionalization) and (ii) a Ushaped relationship overwhelmingly in the COMESA and scantily in the EAC (increasing returns to allocation efficiency from globalization-fueled regionalization). These relationships are relevant to specific globalization dynamics within regions. Economic and monetary regions are more prone to surplus liquidity than pure economic regions. The findings should be understood as correlations because the analysis does not claim to establish causality. Policy implications and measures of fighting surplus liquidity have also been proposed.

Further research could focus on directly assessing the interactive effect of trade and financial openness on financial allocation efficiency to investigate the hypothesis of simultaneous trade and financial liberalization as an essential condition for obtaining benefits from financial allocation efficiency. Moreover, using more recent data and appropriate time series estimation techniques to assess whether the established findings withstand empirical scrutiny within country-specific frameworks is also worthwhile for identifying targeted or country-specific policy implications. In considering these future research avenues, composite indicators are also readily available in the databases of the International Monetary Fund and other international development institutions. The study does not measure regionalization policies in a strict sense, but uses policy dummies based on the date from which the treaty of the regional body was enforced by the respective countries. Hence, future studies should consider more in-depth policy variables to verify our findings, notably the opposite effects found in the UEMOA and CEMAC compared to the COMESA and EAC. 


\section{Appendix 1}

Table 6 Segments of the financial system by degree of formality in Paper's context

\begin{tabular}{|c|c|c|c|c|c|c|}
\hline \multicolumn{3}{|c|}{ Paper's context } & \multirow{2}{*}{$\begin{array}{l}\text { Tiers } \\
\text { Formal } \\
\text { banks }\end{array}$} & \multirow[t]{2}{*}{ Definitions } & \multirow{2}{*}{$\begin{array}{l}\text { Institutions } \\
\text { Commercial and } \\
\text { development } \\
\text { banks }\end{array}$} & \multirow{2}{*}{$\begin{array}{l}\text { Principal Clients } \\
\text { Large businesses, } \\
\text { Government }\end{array}$} \\
\hline $\begin{array}{l}\text { Formal } \\
\text { financial } \\
\text { system }\end{array}$ & & $\begin{array}{l}\text { Formal } \\
\text { Financial } \\
\text { sector } \\
\text { (Deposit } \\
\text { Banks) }\end{array}$ & & & & \\
\hline \multirow[t]{3}{*}{$\begin{array}{l}\text { Semi- } \\
\text { formal } \\
\text { and } \\
\text { informal } \\
\text { financial } \\
\text { systems }\end{array}$} & $\begin{array}{l}\text { IMF Definition } \\
\text { of Financial } \\
\text { System from } \\
\text { International } \\
\text { Financial } \\
\text { Statistics (IFS) }\end{array}$ & $\begin{array}{l}\text { Semi- } \\
\text { formal } \\
\text { financial } \\
\text { sector } \\
\text { (Other } \\
\text { Financial } \\
\text { Institutions) }\end{array}$ & $\begin{array}{l}\text { Specialized } \\
\text { non-bank } \\
\text { financial } \\
\text { institutions }\end{array}$ & $\begin{array}{l}\text { Licensed by } \\
\text { central bank }\end{array}$ & $\begin{array}{l}\text { Rural banks, Post } \\
\text { banks, Saving } \\
\text { and Loan } \\
\text { Companies, } \\
\text { Deposit taking } \\
\text { Micro Finance } \\
\text { banks }\end{array}$ & $\begin{array}{l}\text { Large rural } \\
\text { enterprises, } \\
\text { Salaried Workers, } \\
\text { Small and } \\
\text { medium } \\
\text { enterprises }\end{array}$ \\
\hline & & & $\begin{array}{l}\text { Other non- } \\
\text { bank finan- } \\
\text { cial } \\
\text { institutions }\end{array}$ & $\begin{array}{l}\text { Legally registered } \\
\text { but not licensed } \\
\text { as financial } \\
\text { institution by } \\
\text { central bank and } \\
\text { government }\end{array}$ & $\begin{array}{l}\text { Credit Unions, } \\
\text { Micro Finance } \\
\text { NGOs }\end{array}$ & $\begin{array}{l}\text { Microenterprises, } \\
\text { Entrepreneurial } \\
\text { poor }\end{array}$ \\
\hline & $\begin{array}{l}\text { Missing } \\
\text { component in } \\
\text { IFS definition }\end{array}$ & $\begin{array}{l}\text { Informal } \\
\text { financial } \\
\text { sector }\end{array}$ & $\begin{array}{l}\text { Informal } \\
\text { banks }\end{array}$ & $\begin{array}{l}\text { Not legally } \\
\text { registered at } \\
\text { national level } \\
\text { (though may be } \\
\text { linked to a } \\
\text { registered } \\
\text { association) }\end{array}$ & $\begin{array}{l}\text { Savings } \\
\text { collectors, } \\
\text { Savings and } \\
\text { credit } \\
\text { associations, } \\
\text { Money lenders }\end{array}$ & $\begin{array}{l}\text { Self-employed } \\
\text { poor }\end{array}$ \\
\hline
\end{tabular}

Source: Asongu and Acha-Anyi (2017)

\section{Appendix 2}

Table 7 Definitions and Sources of Variables

\begin{tabular}{lll}
\hline Variable(s) & Definitions of Variables (Measurements) & Source(s) \\
\hline Banking efficiency & Bank system credit on Banking system deposits & FDSD (World Bank) \\
Financial efficiency & Financial system credit on Financial system deposits (\%) & ADI (World Bank) \\
Imports & Imports of goods and services (\% of GDP) & Exports of goods and services (\% of GDP) \\
Trade Globalisation & Imports plus Exports of goods and services (\% of GDP) \\
Foreign investment & Gross Foreign Direct Investment (\% of GDP) \\
Private Capital Flows & Gross Private Capital Flows (\% of GDP) \\
Financial Globalisation & First PC of Foreign Investment and Private Capital Flows \\
Globalisation & First PC of Financial Globalisation and Trade Globalisation \\
Economic growth & Gross Domestic Product (GDP) Growth (annual \%) \\
Inflation & Annual Consumer Price Index \\
Public Investment & Gross Public Investment (\% of GDP) \\
Foreign Aid & Total Development Assistances (\% of GDP) \\
\hline PC Principal &
\end{tabular}




\section{Appendix 3}

Table $\mathbf{8}$ Openness and financial data

\begin{tabular}{|c|c|c|c|c|c|c|}
\hline \multirow[t]{3}{*}{ Variables } & \multicolumn{6}{|c|}{ Panel A: Globalization (Openness) } \\
\hline & \multicolumn{3}{|c|}{ Financial Openness(F.O) } & \multicolumn{3}{|c|}{ Trade Openness(T.O) } \\
\hline & GPCFgdp & GFDlgdp & Finopex & $\operatorname{lgdp}$ & Xgdp & Tropex \\
\hline Definitions & $\begin{array}{l}\text { Gross Private } \\
\text { Capital Flows } \\
\text { on GDP }\end{array}$ & $\begin{array}{l}\text { Gross Foreign Direct } \\
\text { Investment on GDP }\end{array}$ & $\begin{array}{l}\text { Financial } \\
\text { Openness Index }\end{array}$ & $\begin{array}{l}\text { Imports } \\
\text { on GDP }\end{array}$ & $\begin{array}{l}\text { Exports } \\
\text { on GDP }\end{array}$ & $\begin{array}{l}\text { Imports plus } \\
\text { Exports on } \\
\text { GDP }\end{array}$ \\
\hline Sources & $\mathrm{ADI}$ & $\mathrm{ADI}$ & PCA & $\mathrm{ADI}$ & $\mathrm{ADI}$ & $A D I$ \\
\hline $\begin{array}{l}\text { Usages in the } \\
\text { Openness } \\
\text { literature }\end{array}$ & \multicolumn{2}{|c|}{$\begin{array}{l}\text { Lane and Milesi-Ferreti (2006), Bal- } \\
\text { tagi et al. (2009), Hanh (2010) }\end{array}$} & Gries et al. (2009) & \multicolumn{2}{|c|}{ Standard Proxies } & $\begin{array}{l}\text { Hanh (2010), } \\
\text { Gries et al. } \\
(2009)\end{array}$ \\
\hline \multirow[t]{3}{*}{ Variables } & \multicolumn{6}{|c|}{ Panel B: Principal Financial Development Indicators } \\
\hline & Depth & Efficiency & Size & \multicolumn{2}{|l|}{ Activity } & DESA-1 \\
\hline & $\| g d p$ & bcbd & dbacba & \multicolumn{2}{|l|}{ prdcgdp } & Findex 1 \\
\hline Definitions & $\begin{array}{l}\text { Liquid liability } \\
\text { on GDP }\end{array}$ & $\begin{array}{l}\text { Bank Credit on Bank } \\
\text { Deposits }\end{array}$ & $\begin{array}{l}\text { Deposit bank } \\
\text { assets on Total } \\
\text { financial assets }\end{array}$ & \multicolumn{2}{|c|}{$\begin{array}{l}\text { Private credit by } \\
\text { domestic banks } \\
\text { on GDP }\end{array}$} & $\begin{array}{l}\text { Financial } \\
\text { development } \\
\text { Index } 1\end{array}$ \\
\hline Sources & FDSD & FDSD & FDSD & \multicolumn{2}{|l|}{ FDSD } & PCA \\
\hline $\begin{array}{l}\text { Usages in the } \\
\text { Financial } \\
\text { development } \\
\text { literature }\end{array}$ & $\begin{array}{l}\text { Hanh (2010), } \\
\text { Gries et al. } \\
\text { (2009) }\end{array}$ & \multicolumn{2}{|c|}{$\begin{array}{l}\text { Demirguc-Kunt et al. (1999), Demirguc- } \\
\text { Kunt and Beck (2009) }\end{array}$} & \multicolumn{2}{|c|}{$\begin{array}{l}\text { Baltagi et al. } \\
(2009) \text {, Hanh } \\
(2010)\end{array}$} & $\begin{array}{l}\text { Gries et al. } \\
\text { (2009) }\end{array}$ \\
\hline \multirow[t]{3}{*}{ Variables } & \multicolumn{6}{|c|}{ Panel C: Robustness tests financial development Indicators } \\
\hline & Depth & Efficiency & Size & \multicolumn{2}{|l|}{ Activity } & DESA-2 \\
\hline & fdgdp & prdefsd & $?$ & \multicolumn{2}{|c|}{ prdcofgdp } & Findex 2 \\
\hline Definitions & $\begin{array}{l}\text { Financial } \\
\text { system } \\
\text { deposits on } \\
\text { GDP }\end{array}$ & $\begin{array}{l}\text { Private domestic } \\
\text { credit on financial } \\
\text { system deposit }\end{array}$ & & \multicolumn{2}{|c|}{$\begin{array}{l}\text { Private credit } \\
\text { from domestic } \\
\text { banks and other } \\
\text { financial } \\
\text { institutions }\end{array}$} & $\begin{array}{l}\text { Financial } \\
\text { development } \\
\text { index }\end{array}$ \\
\hline Sources & FDSD & FDSD & $?$ & \multicolumn{2}{|l|}{ FDSD } & PCA \\
\hline $\begin{array}{l}\text { Usages in the } \\
\text { literature/ } \\
\text { justification }\end{array}$ & $\begin{array}{l}\text { Authors } \\
\text { correlation } \\
\text { analysis }\end{array}$ & $\begin{array}{l}\text { Authors correlation } \\
\text { analysis }\end{array}$ & $?$ & \multicolumn{2}{|c|}{$\begin{array}{l}\text { Authors } \\
\text { correlation } \\
\text { analysis }\end{array}$} & $\begin{array}{l}\text { Gries et al. } \\
\text { (2009) }\end{array}$ \\
\hline
\end{tabular}

ADI African Development Indicators. PCA Principal Component Analysis. FDSD Financial Development and Structure Database 


\section{Appendix 4}

Table 9 Summary Statistics

\begin{tabular}{|c|c|c|c|c|c|c|c|c|c|c|}
\hline & Mean & S.D & Min. & Max & Obs. & Mean & S.D & Min. & Max & Obs. \\
\hline & \multicolumn{5}{|l|}{ UEMOA } & \multicolumn{5}{|l|}{ CEMAC } \\
\hline Banking System Efficiency & 1.248 & 0.604 & 0.338 & 3.698 & 145 & 0.806 & 0.298 & 0.188 & 1.601 & 57 \\
\hline Financial System Efficiency & 117.52 & 48.413 & 41.300 & 234.39 & 125 & 79.493 & 27.865 & 22.20 & 160.70 & 53 \\
\hline Imports & 33.055 & 6.929 & 17.836 & 51.780 & 138 & 35.685 & 15.507 & 14.639 & 74.219 & 56 \\
\hline Exports & 24.823 & 9.984 & 13.319 & 52.650 & 138 & 49.452 & 22.803 & 16.179 & 86.884 & 56 \\
\hline Trade Globalisation & 59.015 & 13.678 & 32.781 & 95.007 & 142 & 86.026 & 36.722 & 31.745 & 156.861 & 57 \\
\hline Foreign Investment & 1.018 & 1.421 & -2.496 & 7.246 & 136 & 2.609 & 7.225 & -8.629 & 34.507 & 47 \\
\hline Private Capital Flows & 0.975 & 1.545 & -2.517 & 8.849 & 135 & 2.665 & 7.065 & -8.918 & 34.488 & 47 \\
\hline Financial Globalisation & -0.001 & 1.380 & -2.929 & 6.701 & 135 & 0.000 & 1.412 & -2.259 & 6.306 & 47 \\
\hline Globalisation & 0.062 & 1.009 & -1.973 & 4.032 & 135 & -0.014 & 1.175 & -1.285 & 3.762 & 47 \\
\hline Economic Growth & 2.583 & 4.264 & -16.825 & 12.100 & 145 & 2.203 & 3.549 & -8.932 & 7.700 & 57 \\
\hline Inflation & 4.571 & 7.486 & -7.796 & 38.530 & 130 & 4.121 & 9.144 & -11.686 & 42.439 & 55 \\
\hline Public Investment & 6.758 & 3.093 & 1.853 & 20.358 & 123 & 4.733 & 2.902 & 0.759 & 13.716 & 57 \\
\hline \multirow[t]{2}{*}{ Foreign Aid } & 11.361 & 5.645 & 0.557 & 28.823 & 145 & 4.449 & 4.591 & -0.174 & 23.418 & 57 \\
\hline & \multicolumn{5}{|c|}{ COMESA } & \multicolumn{5}{|l|}{ EAC } \\
\hline Banking System Efficiency & 0.711 & 0.283 & 0.275 & 1.876 & 287 & 0.588 & 0.185 & 0.206 & 1.075 & 57 \\
\hline Financial System Efficiency & 76.392 & 33.572 & 30.532 & 200.079 & 276 & 62.121 & 18.783 & 22.767 & 111.830 & 57 \\
\hline Imports & 37.540 & 21.921 & 7.066 & 114.046 & 288 & 29.340 & 6.486 & 19.098 & 47.707 & 55 \\
\hline Exports & 27.569 & 21.778 & 3.335 & 104.213 & 288 & 18.508 & 7.441 & 7.062 & 38.903 & 55 \\
\hline Trade Globalisation & 64.424 & 42.170 & 11.087 & 202.849 & 290 & 48.225 & 13.260 & 26.609 & 72.858 & 57 \\
\hline Foreign Investment & 1.429 & 2.222 & -4.302 & 9.708 & 260 & 2.016 & 1.827 & 0.000 & 6.470 & 55 \\
\hline Private Capital Flows & 1.415 & 2.271 & -4.322 & 9.611 & 264 & 1.971 & 1.893 & -0.253 & 6.688 & 55 \\
\hline Financial Globalisation & 0.006 & 1.410 & -3.610 & 5.186 & 260 & 0.000 & 1.413 & -1.539 & 3.484 & 55 \\
\hline Globalisation & 0.012 & 1.134 & -1.498 & 4.366 & 260 & -0.024 & 1.113 & -1.903 & 2.876 & 55 \\
\hline Economic Growth & 3.790 & 5.780 & -50.248 & 35.224 & 286 & 4.974 & 2.732 & -0.799 & 11.523 & 57 \\
\hline Inflation & 21.859 & 32.028 & -2.405 & 200.026 & 280 & 13.023 & 10.753 & -0.287 & 45.978 & 57 \\
\hline Public Investment & 6.999 & 3.410 & 0.000 & 17.451 & 268 & 5.559 & 1.851 & 2.492 & 10.452 & 57 \\
\hline Foreign Aid & 12.015 & 10.534 & -0.251 & 94.442 & 290 & 12.294 & 6.280 & 2.407 & 28.992 & 57 \\
\hline
\end{tabular}




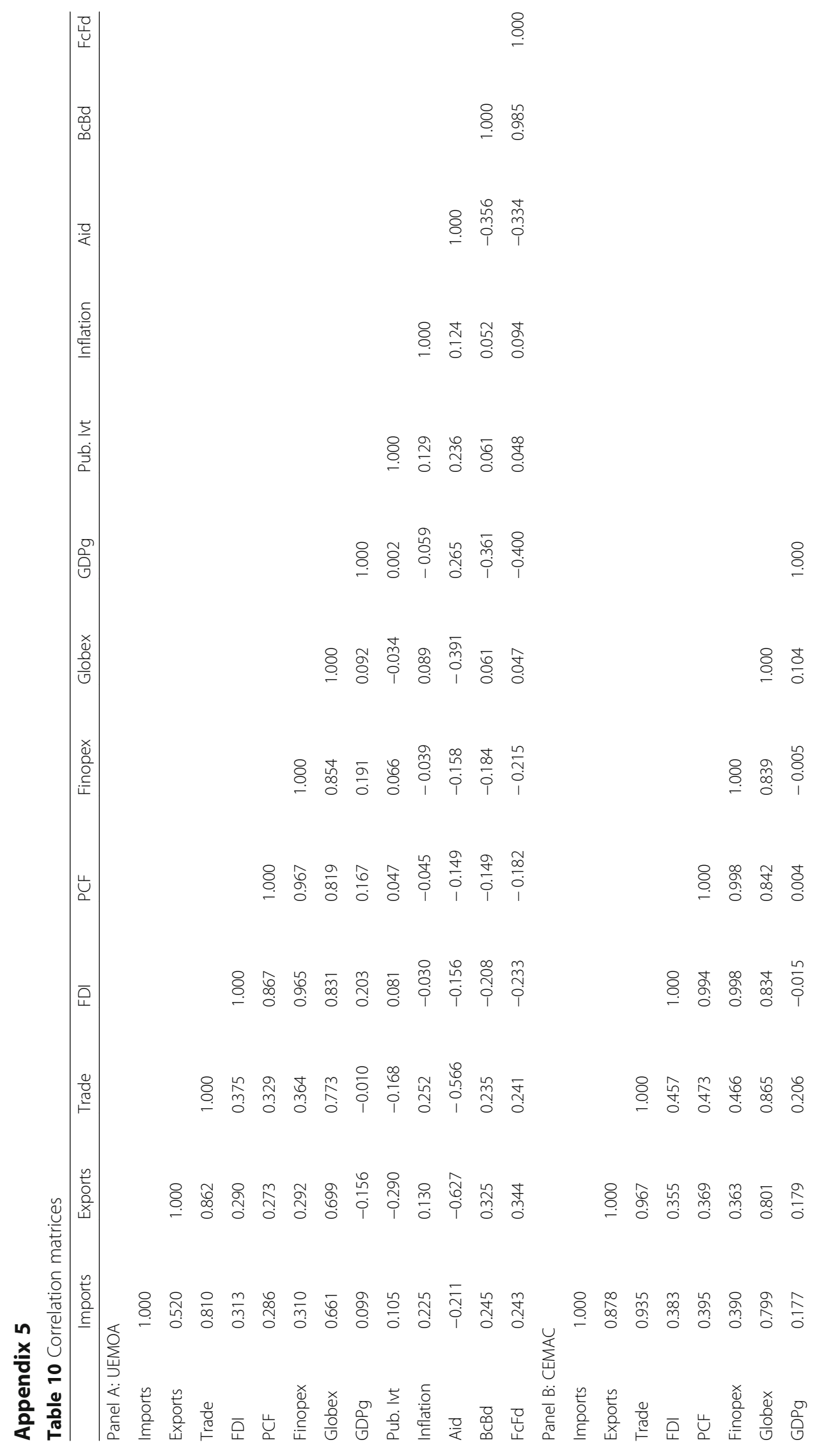




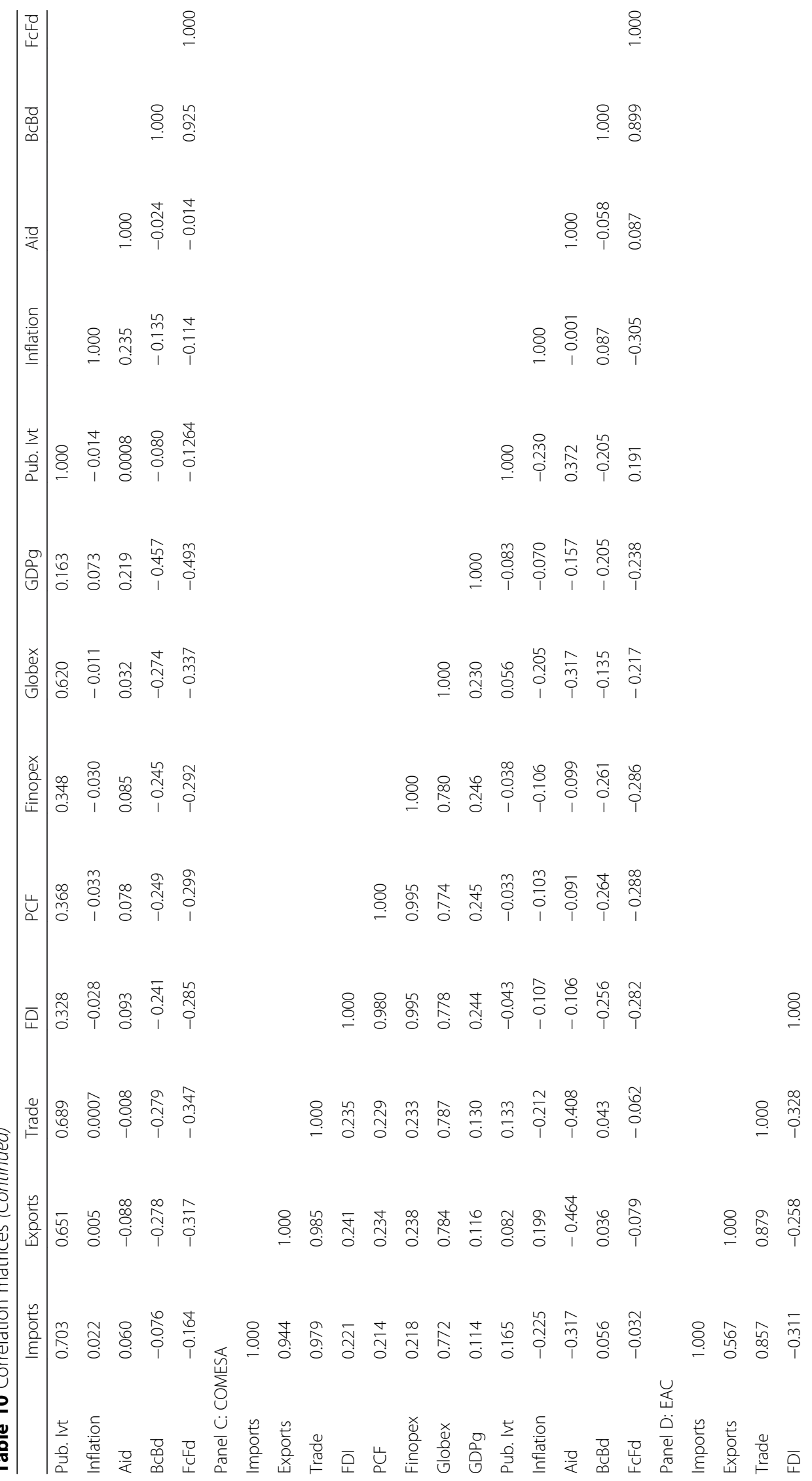




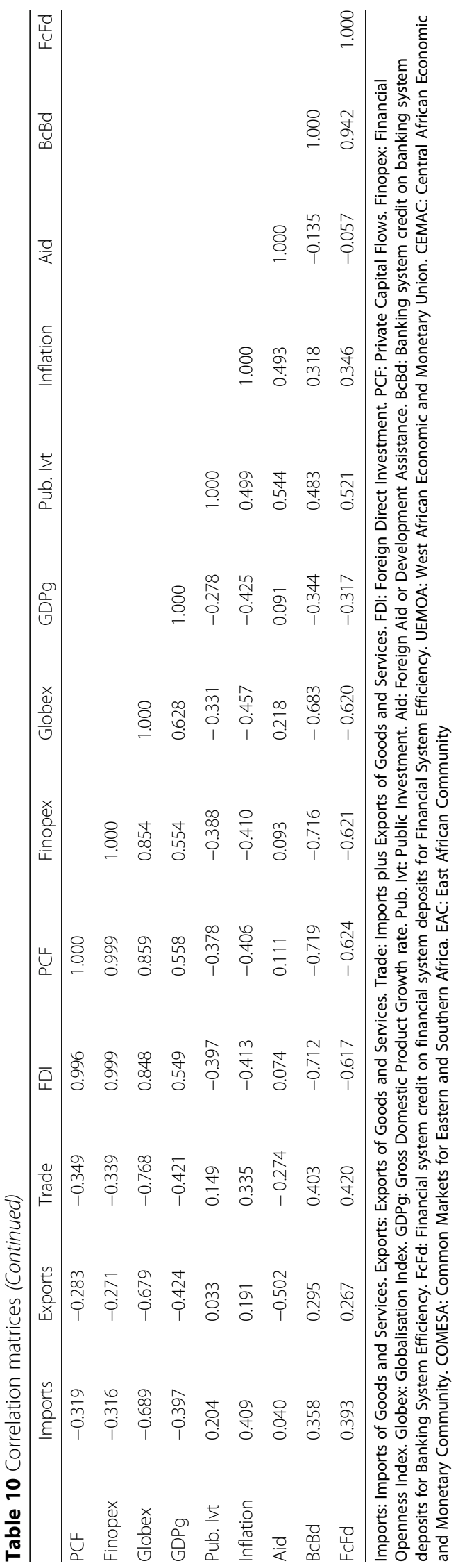




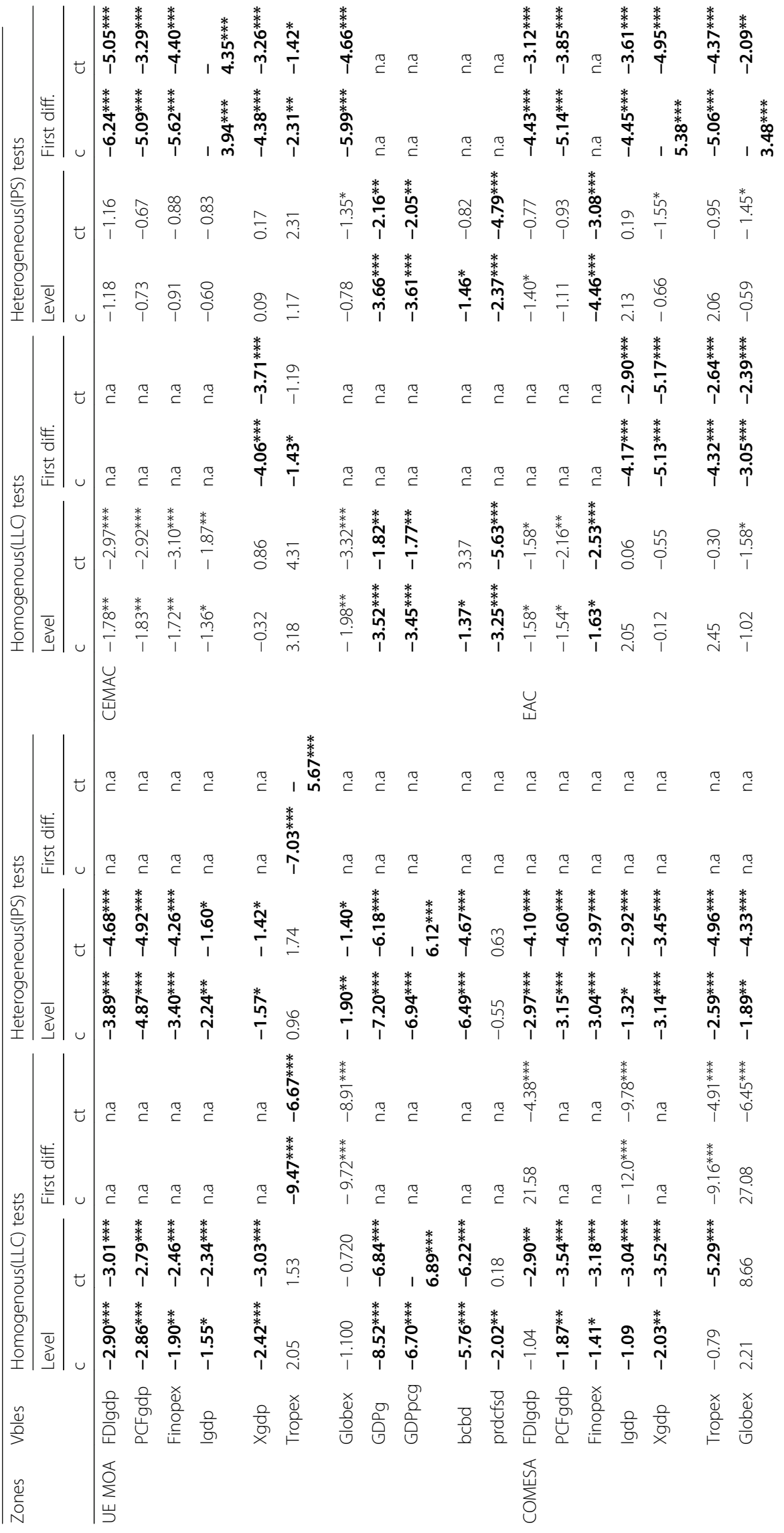




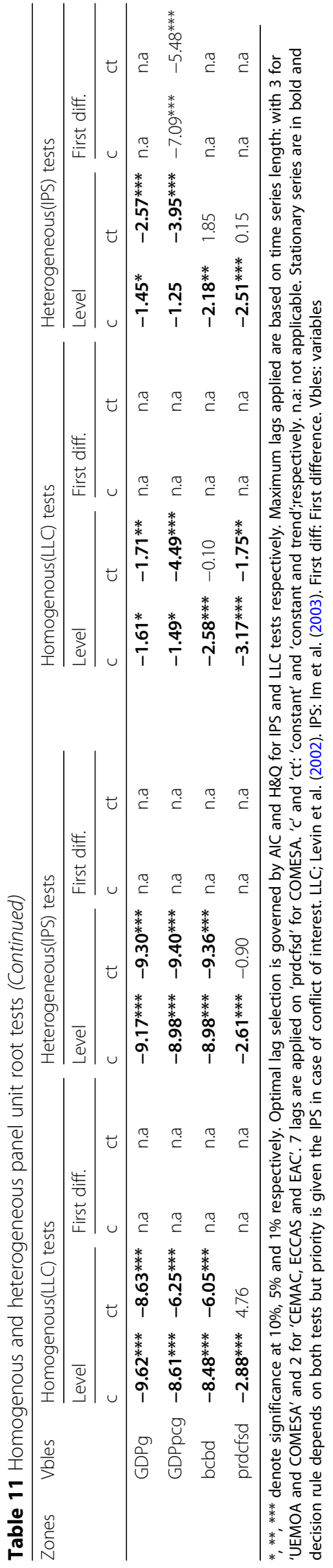




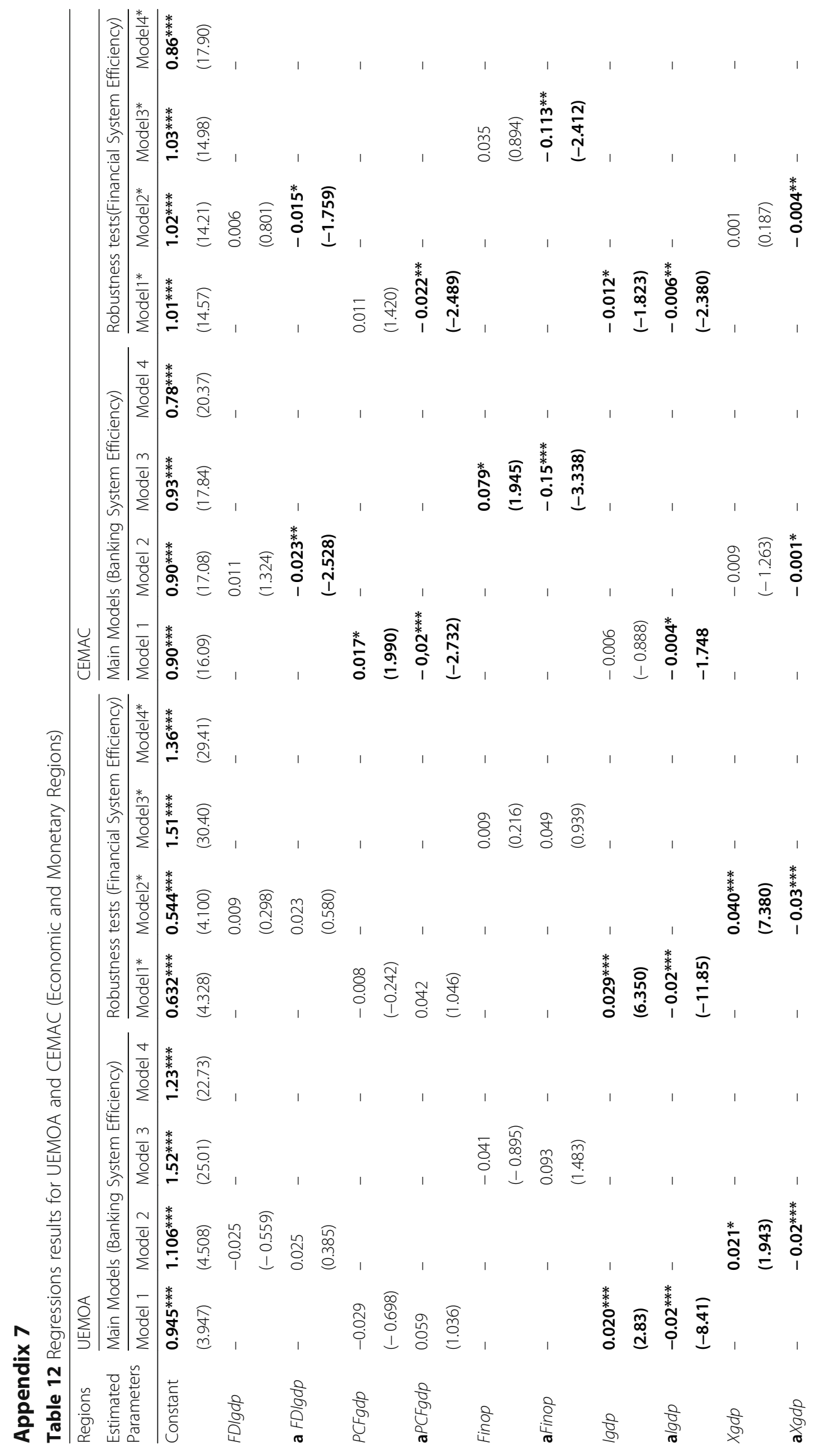




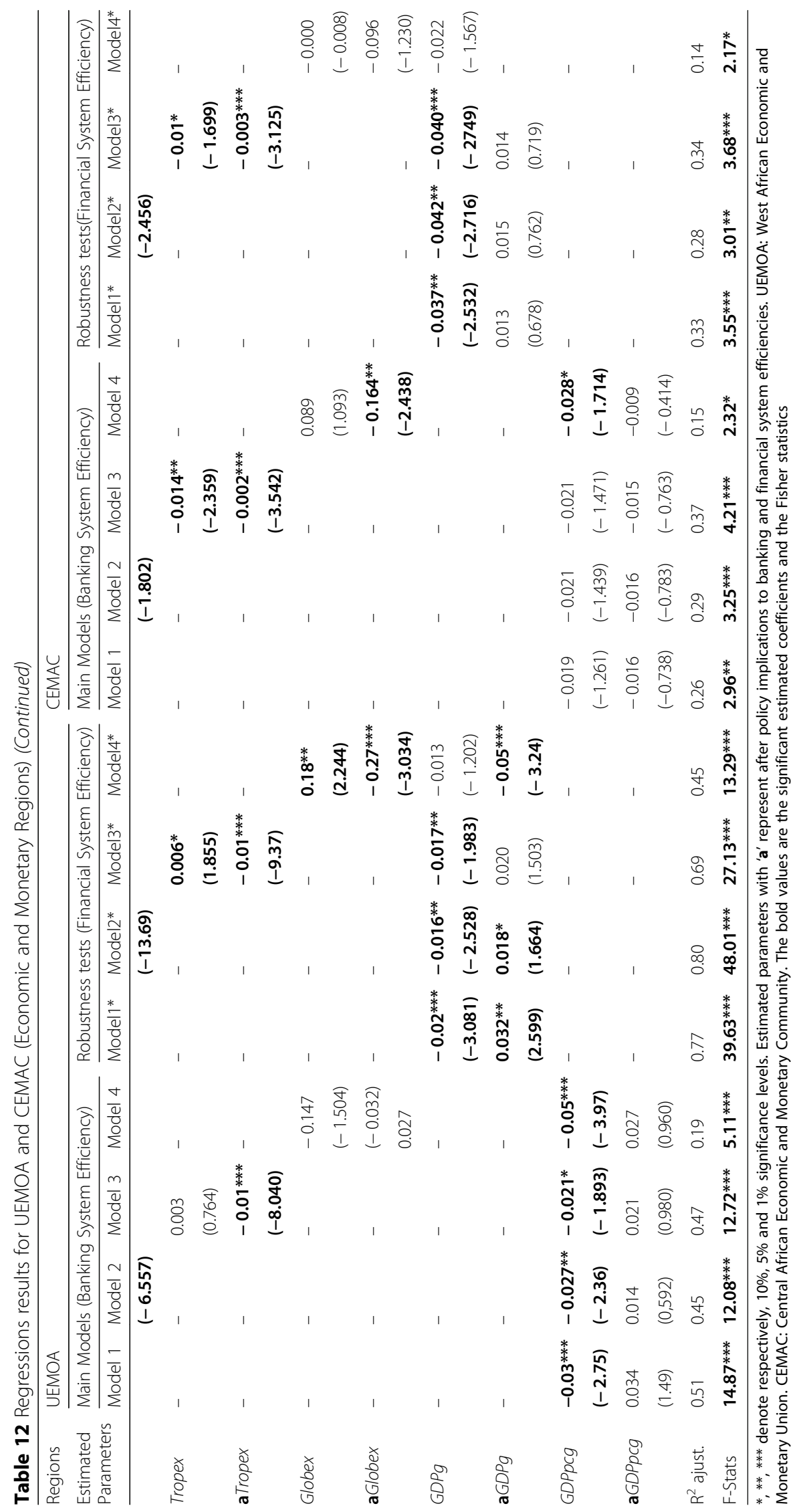




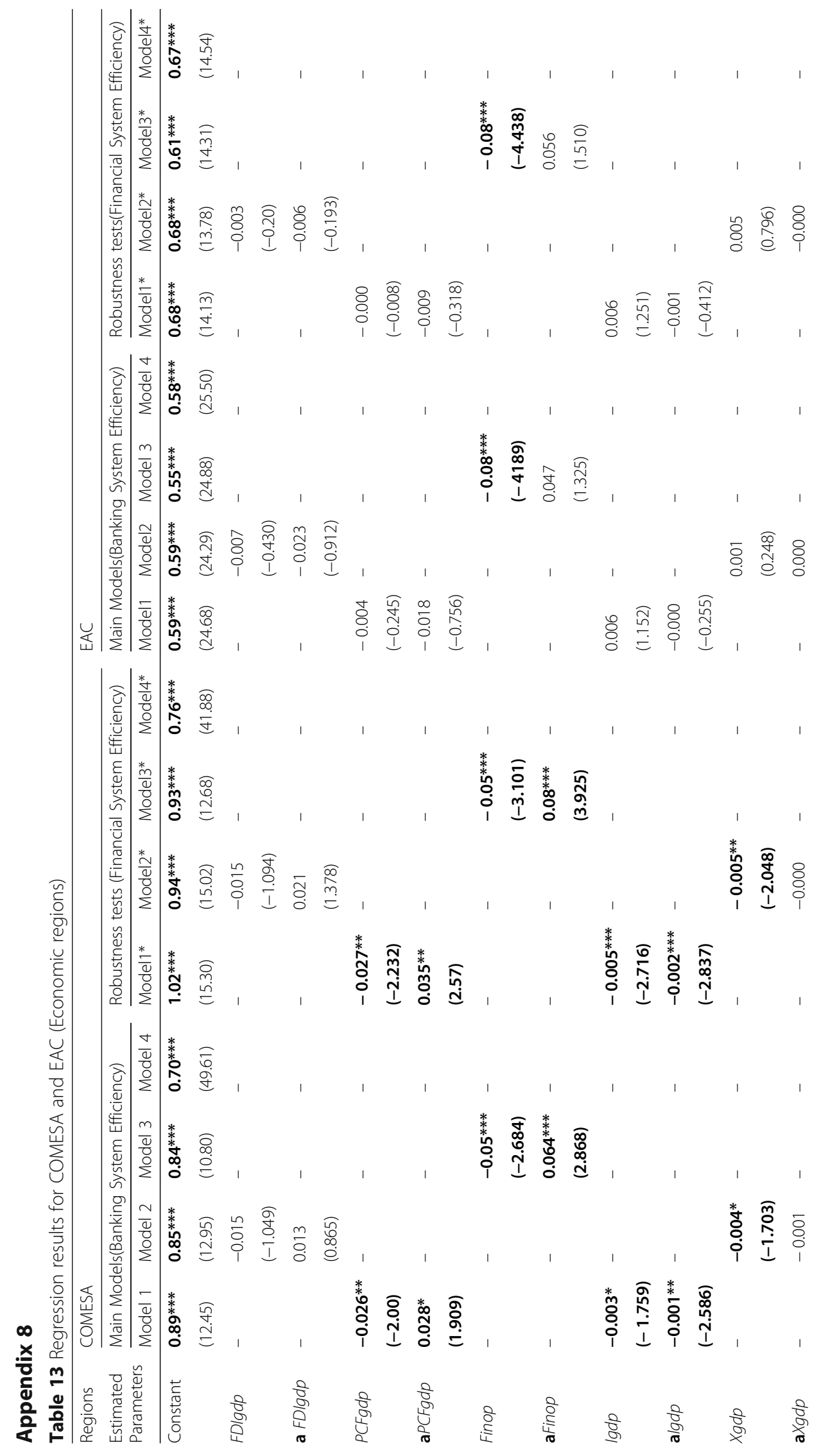




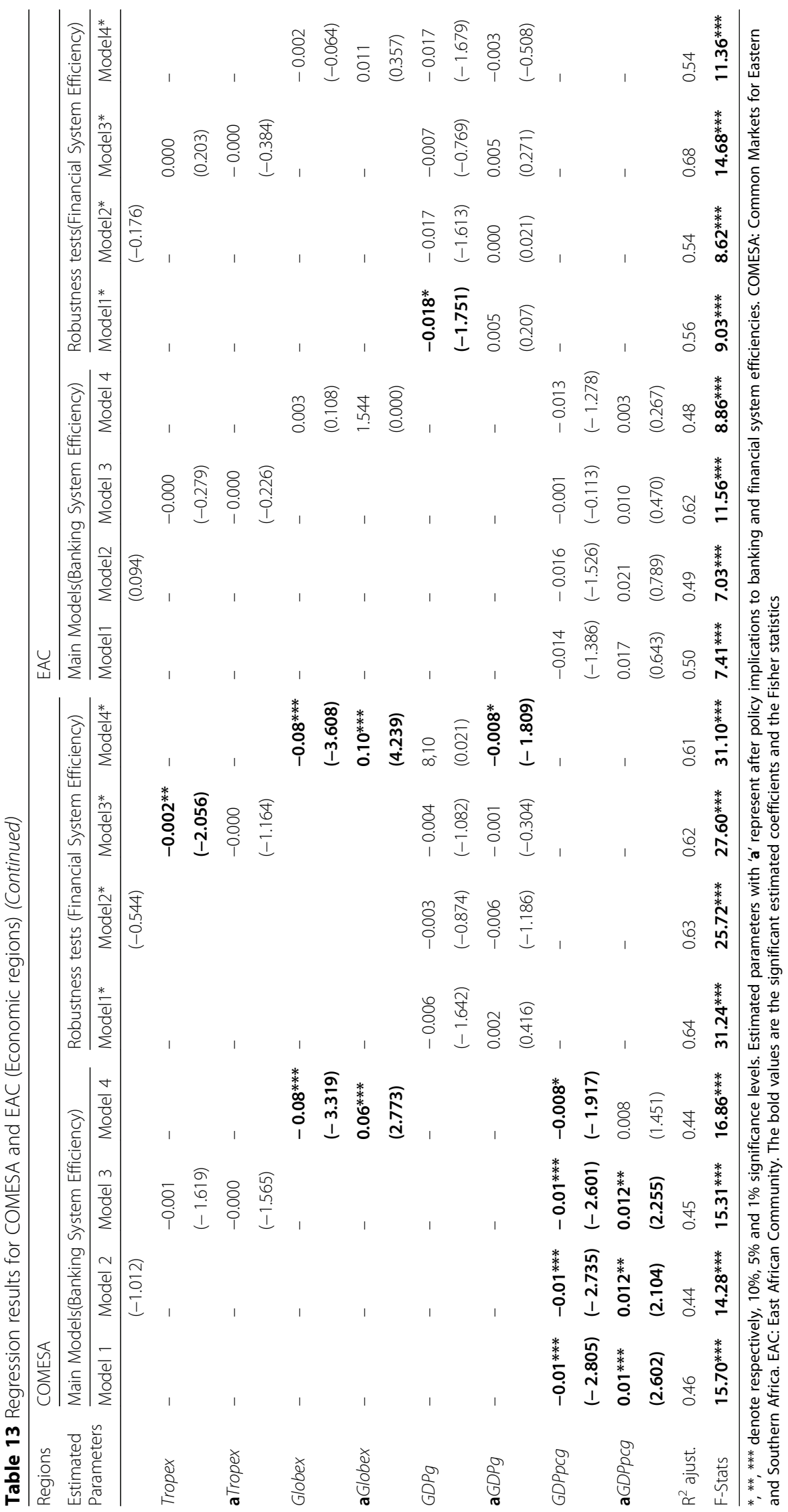




\section{Abbreviations}

ADI: African Development Indicators; AIC: Akaike information criterion; BIC: Bayesian information criterion;

CEMAC: Economic and Monetary Community of Central Africa; CFA: French African Colonies; COMESA: Common Market for East and Southern Africa; DEA: Data envelopment analysis; EAC: East African Community; ECCAS: Economic Community of Central African States; ECOWAS: Economic Community of West African States; EMU: European Monetary Union; FDI: Foreign direct investment; FDSD: Financial Development and Structure Database; FE: Fixed effect; Finopex: Financial globalization indicator; FPE: Final prediction error; GLS: Generalized least squares; HAC: Heteroscedasticity and autocorrelation consistent; HQC: Hannan-Quinn information criterion; IGAD: Intergovernmental Authority on Development; IPS: Im, Pesaran, and Shin; LHS: Left hand-side; LLC: Levin, Lin, and Chu; OEE: Overall economic efficiency; OLS: Ordinary least squares; PCA: Principal component analysis; PCF: Private capital flows; PCs: Principal components; RHS: Right hand-side; SACU: South African Customs Union; SADC: Southern African Development Community; SIC: Schwarz information criterion; SSA: Sub-Saharan Africa; UEMOA: West African Economic and Monetary Union; UMA: Arab Maghreb Union

\section{Acknowledgements}

The authors are indebted to the editor and reviewers for constructive comments.

\section{Authors' contributions}

SAA participated in the writing of the manuscript and data analysis. JN participated in the revision of the manuscript. VST participated in the revision of the manuscript. All authors read and approved the final manuscript.

\section{Funding}

This research is not funded by any organization.

\section{Availability of data and materials}

The data for this paper are available upon request.

\section{Ethics approval and consent to participate}

The research is self-funded and the authors have received no funding for this research. The authors also have no conflicts of interest to declare.

This research does not involve any studies on human participants or animals.

\section{Competing interests}

The authors declare that they have no competing interests.

\section{Author details}

${ }^{1}$ African Governance and Development Institute, P. O. Box 8413, Yaoundé, Cameroon. ${ }^{2} T$ The Development Bank of Nigeria, The Clan Place, Plot 1386A Tigris Crescent, Maitama, Abuja, Nigeria.

Received: 17 October 2018 Accepted: 15 December 2019

Published online: 02 January 2020

References

Akpan US (2014) Impact of regional road infrastructure improvement on intra-regional trade in ECOWAS. Afr Dev Rev 26(S1): 64-76

Al-Obaidan AM (2008) Efficiency effect of openness in the banking industry of emerging markets. Int Res J Financ Econ 17 : 92-104

An Incremental Classifier Based on Competitive Learning. (n.d.), IEEE Transactions on Systems, Man, and Cybernetics: Systems, 2017. pp. 1-12. https://doi.org/10.1109/TSMC.2017.2761360

Andrés AR, Asongu SA, Amavilah VHS (2015) The impact of formal institutions on knowledge economy. J Knowl Econ 6(4): 1034-1062

Arestis P, Demetriades PO, Fattouh B, Mouratidis K (2002) The impact of financial liberalisation policies on financial development: evidence from developing countries. Int J Financ Econ 7(2):109-121

Ashraf Q, Galor O (2013) The Out of Africa Hypothesis, Human Genetic Diversity,and Comparative Economic Development. Am Econ Rev 103(1):1-46

Asongu S, Nwachukwu JC (2016a) The role of lifelong learning on political stability and non violence: evidence from Africa. J Econ Stud 43(1):141-164

Asongu S, Nwachukwu JC (2016b) Revolution empirics: predicting the Arab spring. Empir Econ 51(2):439-482

Asongu SA (2013a) African Stock market performance dynamics: a multidimensional convergence assessment. J Afr Bus 14(3): 186-201

Asongu SA (2013b) How has politico-economic liberalization affected financial allocation efficiency? Fresh African evidence. Econ Bull 33(1):663-676

Asongu SA (2013c) Real and monetary policy convergence: EMU crisis to the CFA zone. J Financ Econ Policy 5(1):20-38

Asongu SA (2014a) Correcting inflation with financial dynamic fundamentals: which adjustments matter in Africa? J Afr Bus 15(1):64-73

Asongu SA (2014b) Financial development dynamic thresholds of financial globalization: evidence from Africa. J Econ Stud 41(2):166-195

Asongu SA (2014c) Linkages between investment flows and financial development: causality evidence from selected African countries. Afr J Econ Manag Stud 5(3):269-299

Asongu SA (2017) Conditional determinants of Mobile phones penetration and Mobile banking in sub-Saharan Africa. J Knowl Econ 9(1):81-135 
Asongu SA, Acha-Anyi PN (2017) ICT, conflicts in financial intermediation and financial access: evidence of synergy and threshold effects. Netnomics 18(2-3):131-168

Asongu SA, De Moor L, Tchamyou SV (2015a) Pre- and post-crisis dynamics of financial globalisation for financial development in Africa. African Governance and Development Institute Working Paper no. 15/045, Yaoundé

Asongu SA, Efobi U, Beecroft I (2015b) Inclusive human development in pre-crisis times of globalisation-driven debts. Afr Dev Rev 27(4):428-442

Asongu SA, Kodila-Tedika O (2018) Institutions and poverty: a critical comment based on evolving currents and debates. Soc Indic Res 139(1):99-117

Asongu SA, Odhiambo NM (2019a) Insurance policy thresholds for economic growth in Africa. Eur J Dev Res. https://doi.org/ 10.1057/s41287-019-00234-2

Asongu SA, Odhiambo NM (2019b) How enhancing gender inclusion affects inequality: thresholds of complementary policies for sustainable development. Sustain Dev. https://doi.org/10.1002/sd.1977

Ataullah A, Cockerill T, Le H (2004) Financial liberalization and bank efficiency: a comparative analysis of India and Pakistan. Appl Econ 36(17):1915-1924

Ba J, Ng S (2006) Confidence intervals for diffusion index forecasts and inference for factor-augmented regression. Econometrica 74(4):1133-1150

Bai J (2003) Inferential theory for factor models of large dimensions. Econometrica 71(1):135-173

Bai J (2009) Panel data models with interactive fixed effects. Econometrica 77(4):1229-1279

Baltagi BH, Demetriades PO, Law SH (2009) Financial development and openness: evidence from panel data. J Dev Econ 89(2):285-296

Baricako J, Ndongo GXD (2014) Intégration régionale et croissance: Le cas de l'Afrique Centrale. Afr Dev Rev 26(S1):33-51

Batuo ME (2015) The role of telecommunications infrastructure in the regional economic growth of Africa. J Dev Areas 49(1): $313-330$

Batuo ME, Asongu SA (2015) The impact of liberalisation policies on income inequality in African countries. J Econ Stud 42(1): 68-100

Batuo ME, Guidi F, Kupukile M (2010) Financial development and income inequality: evidence from African countries. African Development Bank, Tunis

Boyd JH, Levine R, Smith BD (2001) The impact of inflation on financial sector performance. J Monet Econ 47:221-248

Brambor T, Clark WM, Golder M (2006) Understanding interaction models: improving empirical analyses. Polit Anal 14(1):6382

Chao X, Kou G, Peng Y, Alsaadi FE (2019) Behavior monitoring methods for trade-based money laundering integrating macro and micro Prudential regulation: a case from China. Technol Econ Dev Econ. https://doi.org/10.3846/tede.2019.9383

Charaf-Eddine N, Strauss I (2014) The ten commandments of applied regional integration analysis: the African case. Afr Dev Rev 26(S1):7-20

Chen C (2009) Bank efficiency in sub-Saharan African middle-income countries. IMF Working Paper no. WP/09/14, Washington

Chen G-M, Firth M, Rui OM (2002) Stock market linkages: evidence from Latin America. J Bank Financ 26(6):1113-1141

Cho YJ (1986) Inefficiencies of financial liberalization in the absence of well-functioning equity markets. J Money Credit Bank 18(2):191-199

Claessens S, Demirgüç-Kunt A, Huizinga H (2001) How does foreign entry affect the domestic banking market? J Bank Financ 25(5):891-911

Cummins J (2000) Language, power and pedagogy: bilingual children in the crossfire. Multilingual Matters, Clevedon

Demirguc-Kunt A, Beck T (2009) Financial institutions and markets across countries over time: data and analysis. World Bank Policy Research Working Paper no. 4943, Washington D.C

Demirguc-Kunt A, Beck T, Levine R (1999) A new database on financial development and structure. International Monetary Fund WP 2146, Washington D.C

Easterly W (2005) What did structural adjustment adjust? The association of policies and growth with repeated IMF and World Bank adjustment loans. J Dev Econ 76(1):1-22

Ebaidalla EM, Yahia AM (2014) Performance of intra-COMESA trade integration: a comparative study with ASEAN's trade integration. Afr Dev Rev 26(S1):77-95

Fischer S (1998) Capital account liberalisation and the role of the IMF. In: Should the IMF pursue capital-account convertibility? vol 207. Essays in International Finance, Department of Economics, Princeton University, pp 1-10, Princeton

Fosu AK (2015) Growth, inequality and poverty in sub-Saharan Africa: recent Progress in a global context. Oxf Dev Stud 43(1): 44-59

Fouda OJP (2009) The excess liquidity of banks in franc zone: how to explain the paradox in the CEMAC. Revue Africaine de I'Integration 3(2):1-56

Greenaway-McGrevy R, Han C, Sul D (2012) Asymptotic distribution of factor augmented estimators for panel regression. J Econ 169(1):48-53

Greenwood J, Jovanovic B (1990) Financial development, growth and distribution of income. J Polit Econ 98(5):1076-1107

Gries T, Kraft M, Meierrieks D (2009) Linkages between financial deepening, trade openness, and economic development: causality evidence from sub-Saharan Africa. World Dev 37(12):1849-1860

Hanh PTH (2010) Financial development, financial openness and trade openness: new evidence. CARE - EMR, University of Rouen, Rouen

Hauner D, Peiris SJ (2005) Bank efficiency and competition in low-income countries: The Case of Uganda. IMF Working Paper No. WP/05/240, Washington

Henry PB (2007) Capital account liberalization: theory, evidence and speculation. J Econ Lit 45(4):887-935

Huang Y (2011) Private investment and financial development in a globalised world. Empir Econ 41(1):43-56

Huybens E, Smith BD (1999) Inflation, financial markets and long-run real activity. J Monet Econ 43(2):283-315

Im KS, Pesaran MH, Shin Y (2003) Testing for unit roots in heterogeneous panels. J Econ 115(1):53-74 
Irving J (2005) Regional integration of Stock exchanges in eastern and southern Africa: Progress and prospects. IMF working Paper 05/ 122, Washington

Janine A, Elbadawi IA (1992) Parallel markets, the foreign exchange auction, and exchange rate unification in Zambia. World Bank Policy Working Paper, the World Bank, Washington no. 909

Javid E, Katircioglu ST (2017) The globalization indicators-tourism development nexus: a dynamic panel-data analysis. Asia Pac J Tourism Res 22(11):1194-1205

Jolliffe IT (2002) Principal Component Analysis, 2nd edn. springer, New York

Kablan S (2009) Mesure de l'Efficacité des Banques dans les Pays en Voie de Développement: Le Cas de l'Union Economique et Monetaire Ouest Africaine (UEMOA). Afr Dev Rev 21(2):367-369

Kablan S (2010) Banking efficiency and financial development in sub-Saharan Africa. IMF Working Paper no.10/136, Washington

Kaiser HF (1974) An index of factorial simplicity. Psychometrika 39(1):31-36

Kandiero T, Chitiga M (2003) Trade openness and foreign direct Investment in Africa. Department of Economics, University of Pretoria, Pretoria

Katircioglu S, Zabolotnov A (2019) Role of financial development in economic globalization: evidence from global panel. Appl Econ Lett. https://doi.org/10.1080/13504851.2019.1616058

Kayizzi-Mugerwa S, Anyanwu JC, Conceição P (2014) Regional integration in Africa: an introduction. Afr Dev Rev 26(S1):1-6

Kholdy S, Sohrabian A (2008) Foreign direct investment, financial markets, and political corruption. J Econ Stud 35(6):486-500

Kim D, Lin S, Suen Y (2010) Dynamic effects of trade openness on financial development. Econ Model 27(1):254-261

Kim SJ, Moshirian F, Wu E (2005) Dynamic stock market integration driven by the European monetary union: an empirical analysis. J Bank Financ 29(10):2475-2502

Kiyota H (2009) Efficiency of commercial banks in sub-Saharan Africa: a comparative analysis of domestic and foreign banks. Asian Development Bank Institute, Tokyo

Kose MA, Prasad ES, Rogoff K, Wei SJ (2006) Financial globalization: a reappraisal. IMF Staff Pap 56(1):8-62

Kose MA, Prasad ES, Taylor AD (2011) Threshold in the process of international financial integration. J Int Money Financ 30(1): $147-179$

Kou G, Chao X, Peng Y, Alsaadi FE (2019a) Machine learning methods combined with financial systemic risk. Technological and Economic Development of Economy. https://doi.org/10.3846/tede.2019.8740

Kou G, Ergu D, Chen Y, Lin C (2016) Pairwise comparison matrix in multiple criteria decision making. Technol Econ Dev Econ 22(5):738-765

Kou G, Lu Y, Peng Y, Shi Y (2012) Evaluation of classification algorithms using MCDM and rank correlation. Int I Inf Technol Decis Making 11(1):197-225

Kou G, Peng Y, Wang G (2014) Evaluation of clustering algorithms for financial risk analysis using MCDM methods. Inf Sci 275(August): $1-12$

Kou G, Yang P, Xiao F, Chen Y, Alsaadi FE (2019b) Evaluation of feature selection methods for text classification with small datasets using multiple criteria decision-making methods. Appl Soft Comput. https://doi.org/10.1016/j.asoc.2019.105836

Kukenova M (2011) Financial liberalization and allocative effective of capital. World Bank Policy Research Working Paper no. 5670, Washington D.C

Lane, R.P. and Milesi-Ferretti G.M. (2006) Capital Flows to Central and Eastern Europe, IIIS Discussion Paper No.161, http:// citeseerx.ist.psu.edu/viewdoc/download?doi=10.1.1.148.9159\&rep=rep1\&type=pdf (Accessed 15 Feb 2018)

Leung HM (2003) External debt and worsening business cycles in less developed countries. J Econ Stud 30(2):155-168

Levin A, Lin CF, Chu CS (2002) Unit root tests in panel data: asymptotic and finite-sample properties. J Econ 108(1):1-24

Levine R (1997) Financial development and economic growth: views and agenda. J Econ Lit 35(2):688-726

Levine R (2003a) More on finance and growth: more finance, more growth. The Federal Reserve Bank of St. Louis, St. Louis July/August

Levine R (2003b) Finance and growth: theory and evidence. In: Aghion, Durlauf (eds) Handbook of economic growth, Amsterdam: Elsevier

Li G, Kou G, Peng Y (2016) A group decision making model for integrating heterogeneous information. IEEE Trans Syst Man Cybern Syst. https://doi.org/10.1109/tsmc.2016.2627050

Li T, Kou G, Peng Y, Shi Y (2014) Classifying with adaptive hyper-spheres

Liew KVS (2004) Which lag selection criteria should we employ. Econ Bull 3(33):1-9

Maddala GS, Wu S (1999) A comparative study of unit root test with panel data and new simple test. Oxf Bull Econ Stat 61(S1):631-652

Mbabazi J, Milner C, Morrissey O (2008) Trade openness, trade cost and growth: why sub-Saharan Africa performs poorly. Centre for Research in Economic Development and International Trade, University of Nottingham, Nottingham

McKenzie CR, McAleer M (1997) On efficient estimation and correct inference in models with generated regressors: a general approach. Japanese Econ Rev 48(4):368-389

Mensah E, Abor J, Aboagye AQQ, Adjasi CKD (2012) In: Menyah K, Abor J (eds) Enhancing the Economic Growth of Africa: Does Banking Sector Efficiency Matter?, Finance and Development in Africa (Research in Accounting in Emerging Economies, Volume 12 Part B). Emerald Group Publishing Limited, pp 1-23, Bingley

Motelle S, Biekpe N (2015) Financial integration and stability in the southern African development community. J Econ Bus 79(may-June, 2015:100-117

Mulwa MR, Emrouznejad A, Murithi FM (2009) Impact of liberalization on efficiency and productivity of sugar industry in Kenya. J Econ Stud 36(3):250-264

Njifen I (2014) L'informalité: un nouveau paradigme de développement et d'intégration «par le bas » en Afrique. Afr Dev Rev 26(S1):21-32

Nshimbi CC, Fioramonti L (2014) The will to integrate: South Africa's responses to regional migration from the SADC region. Afr Dev Rev 26(S1):52-63

Obstfeld M (1998) The global capital market: benefactor or menace? J Econ Perspect 12(4):9-30

Ofa SV, Karingi S (2014) Trade in intermediate inputs and trade facilitation in Africa's regional integration. Afr Dev Rev 26(S1): 96-110 
Okeahalam CC (2001) Strategic alliances and mergers of financial exchanges: the case of the SADC. Centre for the Study of African Economies, Oxford University, Oxford

Oxley L, McAleer M (1993) Econometric issues in macroeconomic models with generated regressors. J Econ Surv 7(1):1-40 Pagan A (1984) Econometric issues in the analysis of regressions with generated regressors. Int Econ Rev 25(1):221-247

Peria M, Soledad M, Mody A (2003) How foreign participation and market concerntration impact bank spreads: evidence from latin America. World Bank, Washington D.C

Pesaran MH (2006) Estimation and inference in large heterogeneous panels with a multifactor error structure. Econometrica 74(4):967-1012

Price GN, Elu JU (2014) Does regional currency integration ameliorate macroeconomic shocks in sub-Saharan Africa? The case of the 2008-2009 global financial crisis. J Econ Stud 41(5):737-750

Rajan RG, Zingales $L$ (2003) The great reversals: the politics of financial development in the twentieth century. J Financ Econ 69(1):5-50

Rodrik D (1998) "Who needs capital-account convertibility?" essays in international finance, no. 207. Princeton University, Princeton

Rodrik D, Subramanian A (2009) Why did financial globalization disappoint? IMF Staff Pap 56(1):112-138

Rogoff KS (1999) International institutions for reducing global financial instability. J Econ Perspect 13(4):21-42

Roller L-H, Waverman L (2001) Telecommunications infrastructure and economic development: a simultaneous approach. Am Econ Rev 91(4):909-923

Saint Paul G (1992) Technological choice, financial markets and economic development. Eur Econ Rev 36(4):763-781

Sathye M (2003) Efficiency of banks in the developing economy: the case of India. Eur J Oper Res 148(3):662-671

Saxegaard M (2006) Excess liquidity and effectiveness of monetary policy: evidence from sub-Saharan Africa. IMF Working Paper no. 06/115, Washington

Schmukler, S. L., (2004), "Financial Globalization: Gain and Pain for Developing Countries", Federal Reserve Bank of Atlanta Economic Review, Second Quarter, pp. 39-66

Shuaibu M (2015) Trade liberalization and intra-regional trade: a case of selected ECOWAS countries. Afr Dev Rev 27(1):27-40

Solow RM (1956) A contribution to the theory of economic growth. Q J Econ 70(1):65-94

Spatarenu M, Manole V (2010) Trade openness and income: a re-examination. Econ Lett 106(1):1-3

Staub RB, Souza G, Tabak BM (2010) Evolution of bank efficiency in Brazil: a DEA approach. Eur J Oper Res 202(1):204-213

Stock JH, Watson MW (2002) Forecasting using principal components from a large number of predictors. J Am Stat Assoc 97(460):1167-1179

Summers LH (2000) International financial crises: causes, prevention and cures. Am Econ Rev 90(2):1-16

Tchamyou VS (2017) The role of knowledge economy in African business. J Knowl Econ 8(4):1189-1228

Tchamyou VS (2019a) Education, lifelong learning, inequality and financial access: evidence from African countries. Contemp Soc Sci. https://doi.org/10.1080/21582041.2018.1433314

Tchamyou VS (2019b) The role of information sharing in modulating the effect of financial access on inequality. J Afr Bus 20(3):317-338

Tchamyou VS, Erreygers G, Cassimon D (2019) Inequality, ICT and financial access in Africa. Technol Forecast Soc Chang 139(February):169-184

Tumwebaze HK, lijo Al (2015) Regional economic integration and economic growth in the COMESA region, 1980-2010. Afr Dev Rev 27(1):67-77

Umutlu M, Akdeniz L, Altag-Salih A (2010) The degree of financial liberalisation and aggregated stock-return volatility in emerging markets. J Bank Financ 34(3):509-521

Wakeman-Linn J, Wagh S (2008) Regional financial integration: its potential contribution to financial sector growth and development in sub-Saharan Africa. Seminar on African finance for the 21st century at IMF Institute in Tunis, Tunis

Welch KH, Wacziarg R (2008) Trade liberalization growth: new evidence. World Bank Econ Rev 22(2):187-231

Westerlund J, Urbain J-P (2012) "Cross-sectional averages versus principal components", Maastricht University, RM/11/053, Maastricht

Westerlund J, Urbain J-P (2013a) On the estimation and inference in factor-augmented panel regressions with correlated loadings. Econ Lett 119(3):247-250

Westerlund J, Urbain J-P (2013b) On the implementation and use of factor-augmented regressions in panel data. J Asian Econ 28:3-11

World Bank (2015). World Development Indicators', World Bank Publications http://www.gopa.de/fr/news/world-bank-releaseworld-development-indicators-2015. (Accessed 15 Nov 2015)

Yartey CA, Adjasi CK (2007) Stock market development in sub-Saharan Africa: critical issues and challenges. IMF Working Paper no. 07/209, Washington

Yu I-W, Fung K-P, Tam C-S (2010) Assessing the financial market integration in Asia equity markets. J Bank Financ 34(12): 2874-2885

Zhang H, Kou G, Peng Y (2019) Soft consensus cost models for group decision making and economic interpretations. Eur J Oper Res 277(3):964-980

\section{Publisher's Note}

Springer Nature remains neutral with regard to jurisdictional claims in published maps and institutional affiliations. 